\title{
Semitransparent $\mathrm{Sb}_{2} \mathrm{~S}_{3}$ thin film solar cells by ultrasonic spray pyrolysis for use in solar windows
}

\author{
Jako S. Eensalu ${ }^{*}$, Atanas Katerski ${ }^{1}$, Erki Kärber ${ }^{1,2}$, Lothar Weinhardt ${ }^{2,3}$, Monika Blum ${ }^{4}$, \\ Clemens Heske ${ }^{2,3}$, Wanli Yang ${ }^{4}$, Ilona Oja Acik ${ }^{1}$ and Malle Krunks ${ }^{* 1}$
}

\section{Full Research Paper}

\section{Address:}

${ }^{1}$ Department of Materials and Environmental Technology, Tallinn University of Technology, Ehitajate tee 5, 19086, Estonia,

${ }^{2}$ Department of Chemistry and Biochemistry, University of Nevada, Las Vegas (UNLV), 4505 Maryland Parkway, Las Vegas, NV 89154-4003, USA, ${ }^{3}$ Institute for Photon Science and Synchrotron Radiation (IPS), Karlsruhe Institute of Technology (KIT), 76344 Eggenstein-Leopoldshafen, Germany and ${ }^{4}$ Advanced Light Source, Lawrence Berkeley National Laboratory, 1 Cyclotron Road, Berkeley, California, 94720, USA

\section{Email:}

Jako S. Eensalu* - jako.eensalu@taltech.ee; Malle Krunks* -

malle.krunks@taltech.ee

* Corresponding author

\section{Keywords:}

antimony sulfide; semitransparent solar cells; solar windows; thin films; ultrasonic spray pyrolysis
Beilstein J. Nanotechnol. 2019, 10, 2396-2409. doi:10.3762/bjnano. 10.230

Received: 18 July 2019

Accepted: 08 November 2019

Published: 06 December 2019

Associate Editor: N. Motta

(C) 2019 Eensalu et al.; licensee Beilstein-Institut. License and terms: see end of document.

\begin{abstract}
The integration of photovoltaic (PV) solar energy in zero-energy buildings requires durable and efficient solar windows composed of lightweight and semitransparent thin film solar cells. Inorganic materials with a high optical absorption coefficient, such as $\mathrm{Sb}_{2} \mathrm{~S}_{3}\left(>10^{5} \mathrm{~cm}^{-1}\right.$ at $450 \mathrm{~nm}$ ), offer semitransparency, appreciable efficiency, and long-term durability at low cost. Oxide-free throughout the $\mathrm{Sb}_{2} \mathrm{~S}_{3}$ layer thickness, as confirmed by combined studies of energy dispersive X-ray spectroscopy and synchrotron soft X-ray emission spectroscopy, semitransparent $\mathrm{Sb}_{2} \mathrm{~S}_{3}$ thin films can be rapidly grown in air by the area-scalable ultrasonic spray pyrolysis method. Integrated into a ITO/ $\mathrm{TiO}_{2} / \mathrm{Sb}_{2} \mathrm{~S}_{3} / \mathrm{P} 3 \mathrm{HT} / \mathrm{Au}$ solar cell, a power conversion efficiency (PCE) of 5.5\% at air mass 1.5 global (AM1.5G) is achieved, which is a record among spray-deposited $\mathrm{Sb}_{2} \mathrm{~S}_{3}$ solar cells. An average visible transparency (AVT) of $26 \%$ of the back-contact-less ITO/ $\mathrm{TiO}_{2} / \mathrm{Sb}_{2} \mathrm{~S}_{3}$ solar cell stack in the wavelength range of $380-740 \mathrm{~nm}$ is attained by tuning the $\mathrm{Sb}_{2} \mathrm{~S}_{3}$ absorber thickness to $100 \mathrm{~nm}$. In scale-up from $\mathrm{mm}^{2}$ to $\mathrm{cm}^{2}$ areas, the $\mathrm{Sb}_{2} \mathrm{~S}_{3}$ hybrid solar cells show a decrease in efficiency of only $3.2 \%$ for an $88 \mathrm{~mm}^{2} \mathrm{Sb}_{2} \mathrm{~S}_{3}$ solar cell, which retains $70 \%$ relative efficiency after one year of non-encapsulated storage. A cell with a PCE of $3.9 \%$ at 1 sun shows a PCE of $7.4 \%$ at 0.1 sun, attesting to the applicability of these solar cells for light harvesting under cloud cover.
\end{abstract}




\section{Introduction}

Modern buildings, especially high-rise buildings, have a large window area available for building-integrated photovoltaics (BIPV). Covering the windows with semitransparent thin film solar cells creates energy-producing solar windows. In addition to current BIPV technology, solar windows could provide advantageous features: they are mountable during construction, they promise an effective utilization of building space, as well as cost and weight savings, and about half of the building electricity demand can be produced on site [1]. Solar windows can be split into two groups: perforated grids of opaque solar cells, such as silicon, or one continuous semitransparent thin film solar cell (dye-sensitized, perovskite, quantum dot, etc.) [1]. Perforated solar windows, comprised of fragments of crystalline $\mathrm{Si}$ (c-Si) solar cells, have shown a tendency to overheat and underperform in efficiency (PCE) [2,3]. C-Si grids are also considered visually unappealing for solar windows [4]. Accordingly, thin film solar cells, even with lower PCE, are considered more promising for applications in solar windows $[1,4]$.

The fundamental issue of semitransparent solar cells is a tradeoff between high PCE and high average visible transparency (AVT). The AVT of solar cells must be over $20 \%$ to qualify as semitransparent [4]. The PCE and AVT of semitransparent thin film solar cells are listed in the following for reference: dye-sensitized - PCE of $9.2 \%$ at $60 \%$ AVT [5]; polymer PCE of $4.0 \%$ at $66 \%$ AVT [6]; halide perovskite - PCE of $6.4 \%$ at $30 \%$ AVT [7]. Dye-sensitized, organic, and halide perovskite absorbers are generally sensitive to moisture, especially in combination with sunlight and air [8-10]. At present, tremendous research efforts have been allocated worldwide to increase the long-term stability of these solar cells [11]. As minimizing fabrication cost is crucial for commercialization, solar windows would benefit from a fully inorganic absorber that has superior stability towards moisture and air as well as sunlight.

$\mathrm{Sb}_{2} \mathrm{~S}_{3}$ has attractive properties $\left(E_{\mathrm{g}} \approx 1.7 \mathrm{eV}\right.$, absorption coefficient $\alpha \approx 1.8 \times 10^{5} \mathrm{~cm}^{-1}$ at $450 \mathrm{~nm}$, anisotropic structure, inorganic) as a light absorber for conventional and semitransparent photovoltaic use [12-14]. $\mathrm{Sb}_{2} \mathrm{~S}_{3}$ has been incorporated as a solar absorber in photo-electrochemical cells, thin film cells, extremely thin absorber (ETA) cells, and hybrid solar cells based on a planar underlay or on nano- or mesostructured scaffolds [15-22]. Studies on ETA $\mathrm{Sb}_{2} \mathrm{~S}_{3}$ cells, which became the basis for respective hybrid solar cells, were pioneered by the teams of Nair, Nezu, and Hodes in the mid-2000s [19,23,24]. The record PCE of $7.5 \%$, achieved with solar cells based on $\mathrm{Sb}_{2} \mathrm{~S}_{3}$ grown by chemical bath deposition (CBD) into mesoporous $\mathrm{TiO}_{2}$, shows the excellent potential of $\mathrm{Sb}_{2} \mathrm{~S}_{3}$ as a $\mathrm{PV}$ absorber, and the suitability of its fabrication by chemical methods [20]. Until now, semitransparency aspects of $\mathrm{Sb}_{2} \mathrm{~S}_{3}$ solar cells have only been studied by Zimmermann et al., who reported a PCE of $4.25 \%$ for a tin-doped indium oxide (ITO)/ $\mathrm{TiO}_{2} / \mathrm{Sb}_{2} \mathrm{~S}_{3} /$ poly(3-hexylthiophene-2,5-diyl) (P3HT)/Ag solar cell with a $50-70 \mathrm{~nm}$ thick $\mathrm{Sb}_{2} \mathrm{~S}_{3}$ absorber and a nontransparent $125 \mathrm{~nm} \mathrm{Ag}$ back contact [21].

$\mathrm{TiO}_{2}$ is the most commonly used electron transport material (ETM) in $\mathrm{Sb}_{2} \mathrm{~S}_{3}$ solar cells [18,25-32]. $\mathrm{SnO}_{2}$ and $\mathrm{ZnO}$ have also been employed as the planar ETM, with varying success $[33,34]$. Conjugated polymers, e.g., P3HT, Spiro-OMeTAD (2,2',7,7'-tetrakis[ $N, N$-di(4-methoxyphenyl)amino]-9,9'-spirobifluorene), and poly[2,6-(4,4-bis(2-ethylhexyl)-4H-cyclopenta[2,1- $\left.b ; 3,4-b^{\prime}\right]$ dithiophene)-alt-4,7-(2,1,3-benzothiadiazole)] (PCPDTBT), are the most popular organic hole transport materials (HTMs) in $\mathrm{Sb}_{2} \mathrm{~S}_{3}$ solar cell studies because of the high PCE values [17,18,25,27-31,35]. However, planar cells with inorganic HTMs (which are chemically and thermally more stable and have lower cost), such as CuSCN, $\mathrm{NiO}_{x}$, and $\mathrm{V}_{2} \mathrm{O}_{5}$, have also shown comparable efficiencies [26,36,37].

As the performance of PV cells highly depends on the quality of the absorber, the development of fabrication techniques to produce high quality $\mathrm{Sb}_{2} \mathrm{~S}_{3}$ absorber layers, with few grain boundaries and intra-grain defects is essential to enable commercialization of $\mathrm{Sb}_{2} \mathrm{~S}_{3}$-based solar cells [14,38]. The record PCE of $5.77 \%$ was achieved with a planar $\mathrm{TiO}_{2} / \mathrm{Sb}_{2} \mathrm{~S}_{3} /$ P3HT cell by employing an $87 \mathrm{~nm}$ thick $\mathrm{Sb}_{2} \mathrm{~S}_{3}$ thin film absorber grown by atomic layer deposition (ALD) [18], whereas a PCE of $4.25 \%$ was reported when using $\mathrm{Sb}_{2} \mathrm{~S}_{3}$ layers grown by $\mathrm{CBD}$ [21]. Unfortunately, the $\mathrm{Sb}_{2} \mathrm{O}_{3}$ impurity phase, which is considered detrimental to PV performance, unavoidably forms in the bulk of the $\mathrm{Sb}_{2} \mathrm{~S}_{3}$ thin film when it is grown by CBD from an aqueous solution [18]. In 2018, PCE $\approx 5.7 \%$ was achieved for a cell based on a spin-coated $\mathrm{Sb}_{2} \mathrm{~S}_{3}$ absorber, and the same group further increased the PCE of this cell to $6.4 \%$ by $\mathrm{Zn}$ doping during spin-coating of $\mathrm{Sb}_{2} \mathrm{~S}_{3}[39,40]$. Soon after, by doping $\mathrm{Sb}_{2} \mathrm{~S}_{3}$ with $\mathrm{CsOH}$, the PCE of planar $\mathrm{Sb}_{2} \mathrm{~S}_{3}$ solar cells was boosted from $4.3 \%$ to $6.6 \%$ [41]. When looking forward to mass production on meter-sized substrates, however, spin-coating cannot be upscaled due to design limitations [42]. Industrialization is feasible only for low-cost, upscalable methods, to the detriment of both conventional ALD and CBD that require several hours to deposit $100 \mathrm{~nm}$ thick $\mathrm{Sb}_{2} \mathrm{~S}_{3}$ films $[18,20,21]$. Regarding vacuum deposition methods, a PCE of $3.5 \%$ was achieved by thermally evaporating $700 \mathrm{~nm}$ of $\mathrm{Sb}_{2} \mathrm{~S}_{3}$ onto planar CdS. The main drawbacks of thermal evaporation and conventional ALD as vacuum techniques are the high 
energy demand and the need for batch processing, which inflates production costs.

As a potent solution-based chemical deposition method, ultrasonic chemical spray pyrolysis (USP) is capable of rapid, areascalable, roll-to-roll and low-cost in-air deposition of $\mathrm{Sb}_{2} \mathrm{~S}_{3}$ layers without imposing limitations on the substrate size $[43,44]$. A recent paper showed a PCE of $4.6 \%$ in solar cells based on $\mathrm{Sb}_{2}(\mathrm{~S}, \mathrm{Se})_{3}$ grown onto planar CdS by USP, followed by Se vapor annealing at $\approx 400{ }^{\circ} \mathrm{C}$. However, pristine $\mathrm{Sb}_{2} \mathrm{~S}_{3}$ solar cells consistently yielded a PCE below $0.1 \%$ [45]. This clearly illustrates the difficulty of preparing high quality $\mathrm{Sb}_{2} \mathrm{~S}_{3}$ absorber layers by USP. A comparative overview of HTMs, deposition methods and PV parameters of solar cells of planar $\mathrm{TiO}_{2} / \mathrm{Sb}_{2} \mathrm{~S}_{3} / \mathrm{HTM}$ configuration of relevant studies is provided in Table S1 in Supporting Information File 1.

Previously, we observed that the moderate photocurrent density and PCE (of 1.9\%) in solar cells based on $\mathrm{Sb}_{2} \mathrm{~S}_{3}$ layers grown by USP was due to a discontinuity of the $\mathrm{Sb}_{2} \mathrm{~S}_{3}$ layer [28]. In our recent study, we showed that the discontinuity of $\mathrm{Sb}_{2} \mathrm{~S}_{3}$ films grown by USP, and likely other chemical methods, is a result of 3D island growth [46]. We demonstrated that by adapting a two-step sequence, whereby amorphous $\mathrm{Sb}_{2} \mathrm{~S}_{3}$ layers are first deposited by USP and then crystallized by thermal annealing, compact $\mathrm{Sb}_{2} \mathrm{~S}_{3}$ thin films with uniform thickness can be fabricated [46]. Similarly, a two-step procedure to grow compact $\mathrm{Sb}_{2} \mathrm{~S}_{3}$ thin films has become common practice for many deposition techniques [18-20,27,29,31,35,47]. To summarize: in order to achieve progress in the various areas of PV applications, e.g., BIPV, and to increase the availability of PV beyond the state-of-the-art in compliance with ever stricter safety and health regulations, novel thin film solar cell designs are required, using abundant non-toxic materials and implementing cost-effective solar cell fabrication technologies.

The aim of this study was to fabricate state-of-the art hybrid solar cells, based on compact thin films of $\mathrm{Sb}_{2} \mathrm{~S}_{3}$ deposited by USP in air, by optimizing the thickness of the $\mathrm{Sb}_{2} \mathrm{~S}_{3}$ layer, and to consider the influence of cell area, storage time and light intensity on PV performance to investigate their potential for application in semitransparent solar windows. In this study, hybrid solar cells with a maximum PCE of $5.5 \%$ at AM1.5G and an AVT of $26 \%$ without back contact were fabricated. A PCE of $3.2 \%$ was recorded for a solar cell with $88 \mathrm{~mm}^{2}$ area. This is the highest PCE in this size category; so far, the PCE of planar $\mathrm{Sb}_{2} \mathrm{~S}_{3}$ solar cells has only been reported for $\approx 1 \mathrm{~cm}^{2}$ area (by our group). A solar cell with a PCE of $3.9 \%$ at AM1.5G (1 sun) showed a PCE of $7.4 \%$ at 0.1 sun, and $10.2 \%$ at 0.03 sun, demonstrating the suitability of this solar cell for operation in direct sunlight, as well as under full cloud cover.

\section{Results and Discussion Quality assessment of USP-Sb ${ }_{2} \mathrm{~S}_{3}$ thin films} The substrate coverage of $\mathrm{Sb}_{2} \mathrm{~S}_{3}$ layers on a glass/ITO/TiO substrate, annealed in vacuum, depends on the quantity of $\mathrm{Sb}_{2} \mathrm{~S}_{3}$ deposited by USP [46]. Thinner ( $\left.\leq 70 \mathrm{~nm}\right) \mathrm{Sb}_{2} \mathrm{~S}_{3}$ layers contain pin-holes (Figure 1a), whereas thicker ( $\geq 100 \mathrm{~nm}) \mathrm{Sb}_{2} \mathrm{~S}_{3}$ layers fully cover the $\mathrm{TiO}_{2}$ ETM (Figure 1b). As the $\mathrm{Sb}_{2} \mathrm{~S}_{3}$ film thickness is increased from 70 to $100 \mathrm{~nm}$, the average lateral grains size increases from $\approx 5 \mu \mathrm{m}$ (Figure $1 \mathrm{a}$ ) to $\approx 10 \mu \mathrm{m}$ (Figure 1b). An increase in grain size with $\mathrm{Sb}_{2} \mathrm{~S}_{3}$ film thickness has been observed by using both physical deposition techniques and chemical deposition techniques $[16,32,48]$. For reference, the semitransparency of a $5 \times 5 \mathrm{~cm}$ glass $/ \mathrm{ITO} / \mathrm{TiO}_{2} /$ $100 \mathrm{~nm} \mathrm{Sb}_{2} \mathrm{~S}_{3}$ stack, showing an AVT of $26 \%$, is illustrated in a photograph in Figure 1c. The initial results show the excellent perspective of this type of solar cell. However, it should be noted that the AVT requirement for semitransparent solar cells generally refers to the complete stack. Thus, further optimization of the HTM and back contact is needed to attain an AVT in excess of $20 \%$ for the complete solar cell.

As-deposited $\mathrm{Sb}_{2} \mathrm{~S}_{3}$ layers on glass/ITO/TiO $/ 2$ substrate were amorphous (Figure 1d), as only signals of anatase- $\mathrm{TiO}_{2}$ and $\mathrm{In}_{2} \mathrm{O}_{3}$ from the substrate were detected by X-ray diffraction (XRD). In contrast, the XRD pattern of the vacuum-annealed sample matched orthorhombic $\mathrm{Sb}_{2} \mathrm{~S}_{3}$ (ICDD PDF 01-0754012). The Raman spectrum of the as-deposited $\mathrm{Sb}_{2} \mathrm{~S}_{3}$ layer contains two broad bands (Figure 1e), which are characteristic of amorphous $\mathrm{Sb}_{2} \mathrm{~S}_{3}$ [28,46]. After vacuum annealing, characteristic narrower bands of $\mathrm{Sb}_{2} \mathrm{~S}_{3}$ are detected, which is an expected result when crystalline $\mathrm{Sb}_{2} \mathrm{~S}_{3}$ is formed [28,46,49]. No traces of additional phases were detected by either XRD or Raman in any glass/ITO/TiO $/ 2 / \mathrm{Sb}_{2} \mathrm{~S}_{3}$ samples. Chlorine, which could originate from the $\mathrm{SbCl}_{3}$ precursor, was not detected by energy-dispersive X-ray spectroscopy (EDX) in any sample. Furthermore, the atomic ratio of $\mathrm{S}$ to $\mathrm{Sb}$ in the annealed $\mathrm{Sb}_{2} \mathrm{~S}_{3}$ layers was close to the stoichiometric value of 1.5 , as estimated using EDX (Figure S1 in Supporting Information File 1).

Soft X-ray emission spectroscopy (XES) is an element- and site-specific method that allows for the study of the electronic structure and chemical bonding in materials [50-53]. The attenuation length $\left(e^{-1}\right)$ of $\approx 180 \mathrm{eV}$ soft $\mathrm{X}$-rays in $\mathrm{Sb}_{2} \mathrm{~S}_{3}$ is $\approx 83 \mathrm{~nm}$ [54], which makes XES an excellent tool for non-destructively studying the near-surface regions and bulk of thin films [55]. For $50 \mathrm{~nm}$ thick $\mathrm{Sb}_{2} \mathrm{~S}_{3}$ layers, the XES spectra (Figure 2) probe the chemical states in the entire $\mathrm{Sb}_{2} \mathrm{~S}_{3}$ film. The $\mathrm{S} \mathrm{L}_{2,3} \mathrm{XES}$ data in Figure 2 allows three transitions for the $\mathrm{Sb}_{2} \mathrm{~S}_{3}$ films and the reference (denoted as "S 3s", "Sb 5s", and UVB - upper valence band) to be clearly distinguished. These transitions stem from electronic transitions from valence bands into the 

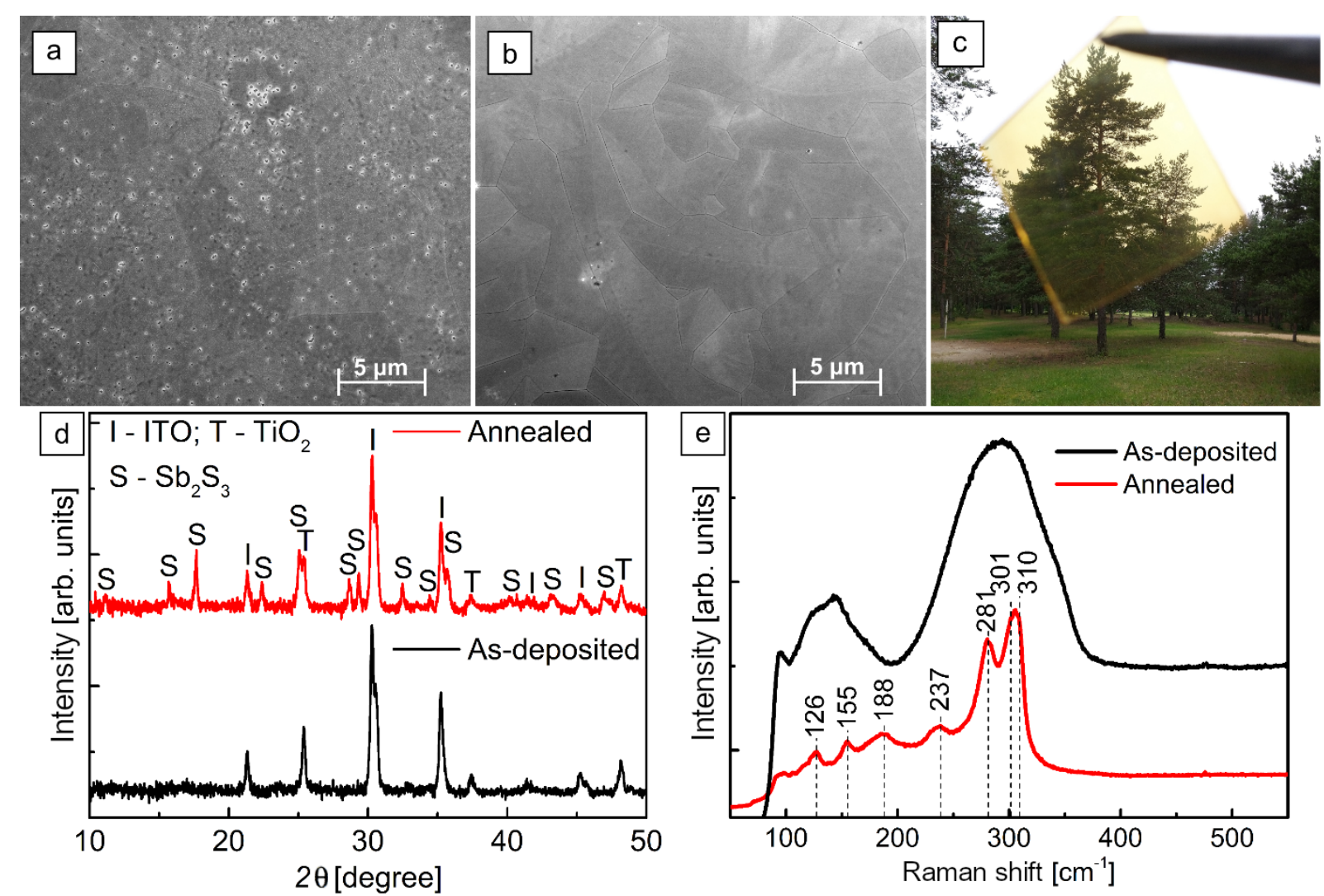

Figure 1: Surface views, by scanning electron microscopy (SEM) of $70 \mathrm{~nm}$ (a) and $100 \mathrm{~nm}$ (b) thick annealed $\mathrm{Sb}_{2} \mathrm{~S}_{3}$ layers on a glass/ITO/TiO 2 sub-

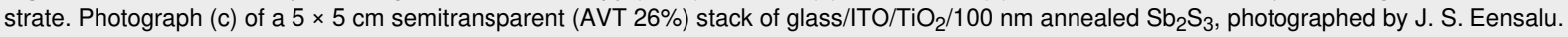
$\mathrm{X}$-ray diffraction patterns (d) and Raman spectra (e) of as-deposited and vacuum-annealed $\mathrm{Sb}_{2} \mathrm{~S}_{3}$ layers on glass/ITO/TiO 2 substrate.

S $2 p$ core holes $\left(\mathrm{S} \mathrm{L}_{2,3}\right)$ created as the initial state of XES. The transition centered at $147.5 \mathrm{eV}$ is predominantly due to $\mathrm{S} 3$ s-derived electronic valence states and appears as the main transition of sulfides [50]. Another peak, as a shoulder for the former, is found at $151 \mathrm{eV}$ and ascribed to $\mathrm{Sb} 5$ s-derived states by comparison with band structure and density of states calculations [50]. Lastly, transitions from the upper valence band of $\mathrm{Sb}_{2} \mathrm{~S}_{3}$ can be found centered at around $156 \mathrm{eV}$. These transitions were identified in line with atom-decomposed density of states prediction in the valence band of $\mathrm{Sb}_{2} \mathrm{~S}_{3}$, calculated from first principles [56].

The overall spectral shape of the $\mathrm{Sb}_{2} \mathrm{~S}_{3}$ thin films, as-prepared and after annealing, agree very well with the $\mathrm{Sb}_{2} \mathrm{~S}_{3}$ reference powder. In contrast, no evidence for $\mathrm{S}-\mathrm{O}$ bonds can be found in the $\mathrm{Sb}_{2} \mathrm{~S}_{3}$ thin film spectra, as can be seen by comparing with the reference spectra of $\mathrm{Sb}_{2}\left(\mathrm{SO}_{4}\right)_{3}$. Sulfate spectra have characteristic line shapes [53]. Thus, the XES study suggests that $\mathrm{S}$ is exclusively bonded to $\mathrm{Sb}$ in the $\mathrm{Sb}_{2} \mathrm{~S}_{3}$ films, throughout its thickness, in the entirety of the analyzed spot size, and both as-deposited and after annealing. The XES study, in addition to the EDX results that showed a $\mathrm{S}$ to $\mathrm{Sb}$ atomic ratio of 1.5 in the layers, provides further assurance that inclusion of $\mathrm{O}$ in the form of a minor impurity phase in the $\mathrm{Sb}_{2} \mathrm{~S}_{3}$ layers is likely negligible. Thus, even without further scrutinizing the layer composition, these results already give USP a distinct advantage over aqueous CBD, wherein the inclusion of oxygen is inevitable and traceable [57-59].

To summarize the thin film characterization, we have fabricated polycrystalline, chlorine-free (below EDX detection limit), and oxygen-free (EDX and XES analysis) $\mathrm{Sb}_{2} \mathrm{~S}_{3}$ thin films by USP in air. To our knowledge, this is the first report on XES experiments for $\mathrm{Sb}_{2} \mathrm{~S}_{3}$ thin films, which, for us, provided the indispensable support of evidence for the claim of the exclusion of oxygen in $\mathrm{Sb}_{2} \mathrm{~S}_{3}$ thin films grown by USP in air.

\section{Development of USP-Sb ${ }_{2} \mathrm{~S}_{3}$ \\ semitransparent solar cells}

Influence of $\mathrm{Sb}_{2} \mathrm{~S}_{3}$ thickness on PV performance of semitransparent $\mathrm{Sb}_{2} \mathrm{~S}_{3}$ solar cells

To investigate the effect of $\mathrm{Sb}_{2} \mathrm{~S}_{3}$ film thickness on PV performance of solar cells, we applied 30, 70, 100, and $150 \mathrm{~nm}$ thick films of USP-Sb $2 \mathrm{~S}_{3}$. By increasing the $\mathrm{Sb}_{2} \mathrm{~S}_{3}$ layer thickness 


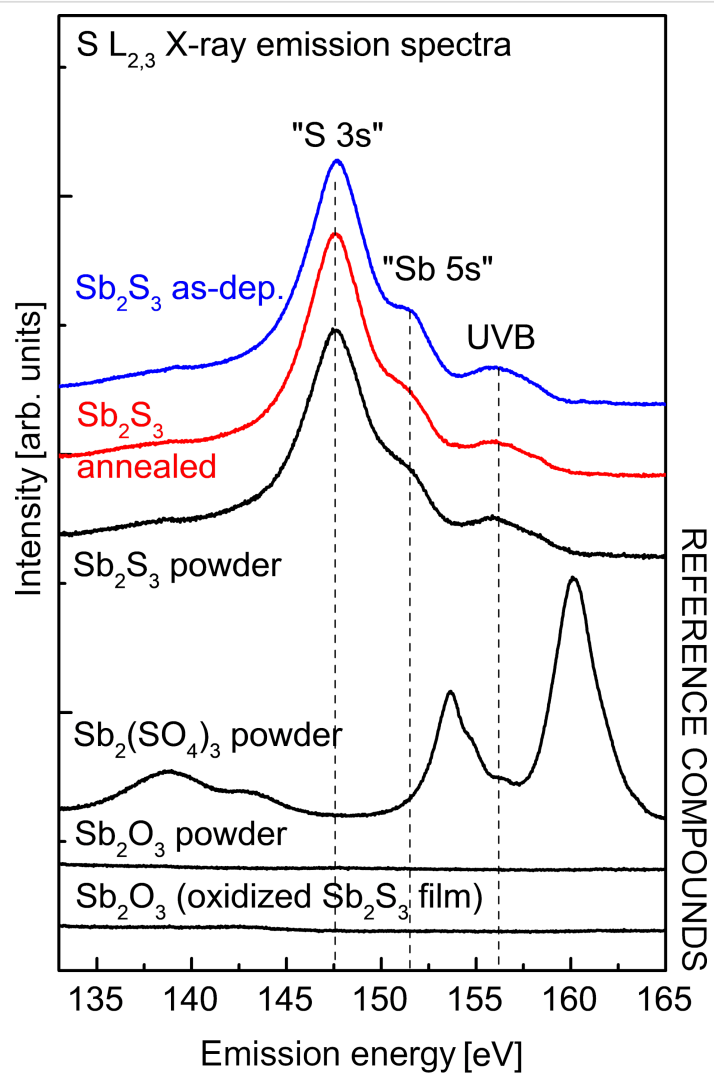

Figure 2: $\mathrm{S}_{2,3}$ XES spectra of two $\mathrm{Sb}_{2} \mathrm{~S}_{3}$ films, as-deposited ("asdep.", blue) and after post-deposition treatment ("annealed", red), both on a glass $/ \mathrm{ITO} / \mathrm{TiO}_{2}$ underlay (excitation energy $180 \mathrm{eV}$ ). Peaks corresponding to electronic transitions from valence states with strong $S 3 \mathrm{~s}$ and $\mathrm{Sb} 5$ s contributions into the $S L_{2,3}$ core holes of the XES initial state, and transitions from the upper valence band (UVB) are indicated. Reference spectra: $\mathrm{Sb}_{2} \mathrm{~S}_{3}$ powder, $\mathrm{Sb}_{2}\left(\mathrm{SO}_{4}\right)_{3}$ powder, $\mathrm{Sb}_{2} \mathrm{O}_{3}$ powder, and an intentionally oxidized $\mathrm{Sb}_{2} \mathrm{~S}_{3}$ film. Note the double-peak structure at $\approx 140 \mathrm{eV}$ in the $\mathrm{Sb}_{2}\left(\mathrm{SO}_{4}\right)_{3}$ spectrum is ascribed to a 2nd order carbon $\mathrm{K}$ emission signal from the support of the powder.

from 30 to $100 \mathrm{~nm}$ in glass/ITO/ $\mathrm{TiO}_{2} / \mathrm{Sb}_{2} \mathrm{~S}_{3} / \mathrm{P} 3 \mathrm{HT} / \mathrm{Au}$ solar cell (Figure $3 \mathrm{a})$, the open-circuit voltage $\left(V_{\mathrm{OC}}\right)$ decreased slightly (704 $\pm 7 \mathrm{mV}$ vs $693 \pm 17 \mathrm{mV})$, the short-circuit current $\left(J_{\mathrm{SC}}\right)$ doubled $\left(4.8 \pm 0.3 \mathrm{~mA} \mathrm{~cm}^{-2}\right.$ vs $\left.10.3 \pm 1.0 \mathrm{~mA} \mathrm{~cm}^{-2}\right)$, the fill factor (FF) increased moderately ( $43 \pm 3 \%$ vs $52 \pm 3 \%$ ), and consequently, the PCE increased by a factor of $\approx 2.5(1.5 \pm 0.1 \%$ vs $3.7 \pm 0.4 \%$ ). The highest $V_{\mathrm{OC}}$ of $726 \mathrm{mV}$ observed in this study is comparable to the highest $V_{\mathrm{OC}}$ of $732 \mathrm{mV}$ reported for planar $\mathrm{TiO}_{2} / \mathrm{Sb}_{2} \mathrm{~S}_{3}$ solar cells, where $\mathrm{Sb}_{2} \mathrm{~S}_{3}$ was grown by chemical bath deposition [21]. Increasing the $\mathrm{Sb}_{2} \mathrm{~S}_{3}$ layer thickness further to $150 \mathrm{~nm}$ causes all photoconversion parameters to plummet; an expected result in the case of increased recombination losses in the bulk of the $\mathrm{Sb}_{2} \mathrm{~S}_{3}$ absorber layer [60]. The FF is adversely affected by large values of series resistance $\left(R_{\mathrm{S}}\right)$ and by small values of shunt resistance $\left(R_{\mathrm{SH}}\right)$ [61]. The cells with $70 \mathrm{~nm}$ thick $\mathrm{Sb}_{2} \mathrm{~S}_{3}$ had the highest FF of $57 \pm 4 \%$, incidentally coinciding with the smallest of $R_{\mathrm{S}}$ and the largest of $R_{\mathrm{SH}}$ whereas the FF was slightly smaller in cells with $100 \mathrm{~nm}$ thick- ness, mostly due to a smaller $R_{\mathrm{SH}}$. Compared to cells with $70-100 \mathrm{~nm}$ thick $\mathrm{Sb}_{2} \mathrm{~S}_{3}$ layers, the FF was smaller by around $10 \%$ in cells with both the thinnest $(30 \mathrm{~nm})$ and the thickest $(150 \mathrm{~nm}) \mathrm{Sb}_{2} \mathrm{~S}_{3}$ layers. The decrease in the FF in these cells could mainly be attributed to the occurrence of $R_{\mathrm{S}}$ over $10 \Omega \mathrm{cm}^{2}$ (Table 1 ). In particular, $R_{\mathrm{S}}$ could be inflated in cells with thin $(30 \mathrm{~nm}) \mathrm{Sb}_{2} \mathrm{~S}_{3}$ layers, because the mobility of charge carriers is likely impeded by numerous grain boundaries owing to the smaller grain size in thinner films. On the other end, $R_{\mathrm{S}}$ is also over $10 \Omega \mathrm{cm}^{2}$ in the cells with overly thick $\mathrm{Sb}_{2} \mathrm{~S}_{3}$ layers $(150 \mathrm{~nm})$, which is ascribed to the ohmic resistance of the thicker absorber. In this study, the resistivity ( $\rho$ ) of 100-150 nm thick $\mathrm{Sb}_{2} \mathrm{~S}_{3}$ films on glass $/ \mathrm{TiO}_{2}$ substrate was measured by the collinear four-wire technique and by van der Pauw measurements to be in the range of $2-3 \times 10^{6} \Omega \mathrm{cm}$, as anticipated.

Figure $3 b$ shows the external quantum efficiency (EQE) of solar cells with 70, 100 and $150 \mathrm{~nm}$ thick $\mathrm{Sb}_{2} \mathrm{~S}_{3}$ thin films and transmittance of solar cells without P3HT/Au back contact. The AVT of the stacks of glass/ITO/TiO $/ 2 / \mathrm{Sb}_{2} \mathrm{~S}_{3}$ with 70,100 , and $150 \mathrm{~nm}$ of $\mathrm{Sb}_{2} \mathrm{~S}_{3}$ is $28 \%, 26 \%$, and $16 \%$, respectively in the $380-740 \mathrm{~nm}$ wavelength range (Figure $3 \mathrm{~b}$ ). Thus, the $150 \mathrm{~nm}$ thick $\mathrm{Sb}_{2} \mathrm{~S}_{3}$ film is already too opaque for it to qualify as a semitransparent absorber layer. According to the EQE, appreciable photoelectric conversion in these cells occurs in the 320-750 nm wavelength range. The observed EQE onset at $750 \mathrm{~nm}$ corresponds to a band gap of $1.65 \mathrm{eV}$ of crystalline $\mathrm{Sb}_{2} \mathrm{~S}_{3}$. Cells with 70 and $100 \mathrm{~nm}$ thick $\mathrm{Sb}_{2} \mathrm{~S}_{3}$ film showed the best EQE values, reaching almost $80 \%$ EQE at around $425 \mathrm{~nm}$ wavelength, which is almost the maximum realistically attainable EQE. The decreased EQE at higher wavelengths is common for solar cells with a chemically deposited $\mathrm{Sb}_{2} \mathrm{~S}_{3}$ absorber [18,21]. The average and best photoconversion parameters calculated from the $J-V$ curves and EQE are presented in Table 1. Compared to $J-V$-derived PV parameters of planar $\mathrm{TiO}_{2} / \mathrm{Sb}_{2} \mathrm{~S}_{3} / \mathrm{HTM}$ solar cells (Supporting Information File 1, Table S1), the PCE achieved in this study for a $1.7 \mathrm{~mm}^{2}$ cell area $(5.5 \%)$ and $7.1 \mathrm{~mm}^{2}$ cell area $(4.7 \%)$ is among the top values achieved in the last five years, and close to the record PCE of planar solar cells based on pristine $\mathrm{Sb}_{2} \mathrm{~S}_{3}$. The mismatch in $J_{\mathrm{SC}}$ calculated from $J-V$ and EQE likely stems from the difference in light intensity during $J-V$ and $\mathrm{EQE}$ measurements, coupled with a strong dependence of photoelectric conversion efficiency on light intensity in these solar cells, as will be discussed later on. The EQE shoulder at around $650 \mathrm{~nm}$ (Figure $3 \mathrm{~b}$ ), indicates the presence of a beneficial phenomenon called the optical spacer effect, which can occur in solar cells with a very thin absorber $[21,62,63]$. The optical spacer effect increases the EQE at above $650 \mathrm{~nm}$, where P3HT does not absorb light. The magnitude of the gain in EQE due to this effect depends on the thickness of the HTM and that of the 

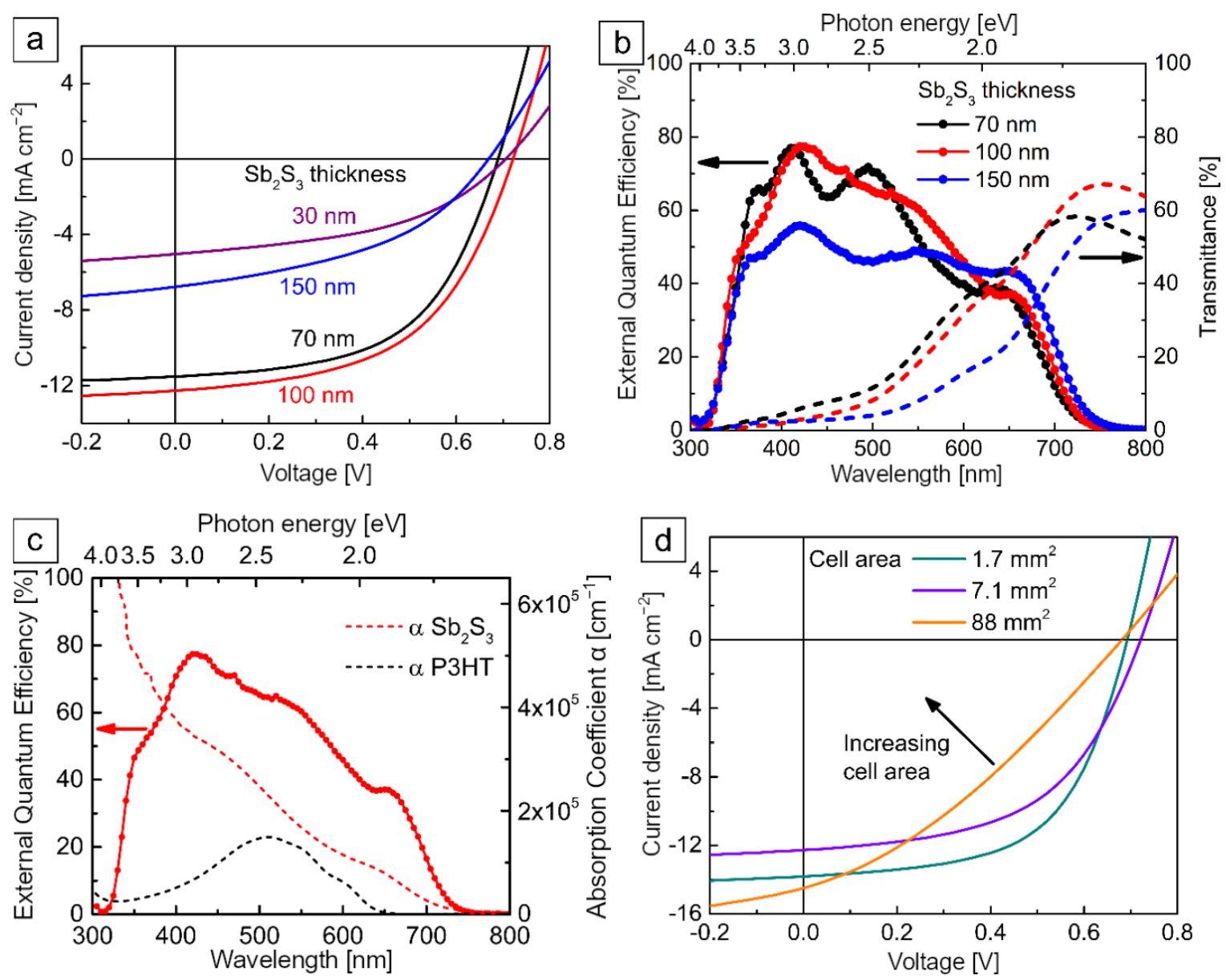

Figure 3: (a) Effect of $\mathrm{Sb}_{2} \mathrm{~S}_{3}$ absorber thickness on $\mathrm{J}-\mathrm{V}$ curves at $\mathrm{AM} 1.5 \mathrm{G}$. (b) EQE of solar cells and transmittance of the glass/ITO/TiO $/ \mathrm{Sb}_{2} \mathrm{~S}_{3}$ stack. (c) EQE of the best-performing solar cell (100 nm Sb $\mathrm{S}_{3}$ ) and absorption coefficients $(\alpha)$ of $\mathrm{Sb}_{2} \mathrm{~S}_{3}$ and P3HT. (d) J-V curves at AM1.5G of $100 \mathrm{~nm} \mathrm{Sb} \mathrm{S}_{3}$ solar cells of different size.

Table 1: Photoconversion parameters ${ }^{\mathrm{a}}$ of solar cells as a function of $\mathrm{Sb}_{2} \mathrm{~S}_{3}$ film thickness. The best results are given in parentheses.

\begin{tabular}{|c|c|c|c|c|c|c|c|c|}
\hline $\mathrm{Sb}_{2} \mathrm{~S}_{3}[\mathrm{~nm}]$ & $V_{\mathrm{OC}}[\mathrm{mV}]$ & $J_{\mathrm{SC}, I-V}\left[\mathrm{~mA} \mathrm{~cm}^{-2}\right]$ & $J_{S C, E Q E}$ & $\mathrm{FF}[\%]$ & PCE [\%] & $R_{\mathrm{S}}\left[\Omega \mathrm{cm}^{2}\right]$ & $R_{\mathrm{SH}}\left[\mathrm{k} \Omega \mathrm{cm}^{2}\right]$ & $\mathrm{Nr}^{\mathrm{b}}$ \\
\hline 30 & $\begin{array}{l}704 \pm 7^{c} \\
(705)\end{array}$ & $\begin{array}{l}4.8 \pm 0.3 \\
(5.00)\end{array}$ & $\overline{-}(6.78)$ & $\begin{array}{l}43 \pm 3 \\
(46)\end{array}$ & $\begin{array}{l}1.5 \pm 0.1 \\
(1.6)\end{array}$ & $\begin{array}{l}14 \pm 2.1 \\
(18)\end{array}$ & $\begin{array}{l}0.5 \pm 0.1 \\
(0.6)\end{array}$ & 8 \\
\hline 70 & $\begin{array}{l}670 \pm 8 \\
(691)\end{array}$ & $\begin{array}{l}7.5 \pm 0.6 \\
(11.5)\end{array}$ & - & $\begin{array}{l}57 \pm 4 \\
(55)\end{array}$ & $\begin{array}{l}2.9 \pm 0.2 \\
(4.4)\end{array}$ & $\begin{array}{l}7.4 \pm 0.6 \\
(6.0)\end{array}$ & $\begin{array}{l}2.2 \pm 1.0 \\
(1.1)\end{array}$ & 9 \\
\hline 100 & $\begin{array}{l}693 \pm 17 \\
(726)\end{array}$ & $\begin{array}{l}10.3 \pm 1.0 \\
(12.3)\end{array}$ & - & $\begin{array}{l}52 \pm 3 \\
(52)\end{array}$ & $\begin{array}{l}3.7 \pm 0.4 \\
(4.7)\end{array}$ & $\begin{array}{l}7.6 \pm 1.5 \\
(5.9)\end{array}$ & $\begin{array}{l}0.9 \pm 0.3 \\
(0.7)\end{array}$ & 36 \\
\hline 150 & $\begin{array}{l}638 \pm 16 \\
(669)\end{array}$ & $\begin{array}{l}4.3 \pm 1.1 \\
(6.88)\end{array}$ & $\begin{array}{l}- \\
(9.60)\end{array}$ & $\begin{array}{l}44 \pm 1 \\
(43)\end{array}$ & $\begin{array}{l}1.2 \pm 0.3 \\
(2.0)\end{array}$ & $\begin{array}{l}26 \pm 5.2 \\
(19)\end{array}$ & $\begin{array}{l}0.7 \pm 0.2 \\
(0.4)\end{array}$ & 8 \\
\hline
\end{tabular}

aMeasurement conditions: $100 \mathrm{~mW} \mathrm{~cm}{ }^{-2}$, AM1.5G, cell active area $7.1 \mathrm{~mm}^{2}$; b Number of measured cells; ' Standard deviation.

absorber [21]. The optical spacer effect can have a strong influence on the EQE when the thickness of the absorber is around $100 \mathrm{~nm}$ or less [62]. Otherwise, most of the incident light is absorbed before reaching the optical spacer layer and the optical spacer effect is not seen. The optical spacer effect is illustrated in the EQE spectrum (Figure 3c) of one of the best-performing devices (100 $\mathrm{nm} \mathrm{Sb}_{2} \mathrm{~S}_{3}, 7.1 \mathrm{~mm}^{2}$ ) coupled with the absorption coefficient curves of $\mathrm{Sb}_{2} \mathrm{~S}_{3}$ and P3HT. The transmittance of light to the absorber is limited at higher photon energies by the onset of absorption of $\mathrm{TiO}_{2}$ at $3.0 \mathrm{eV}$ and ITO at $3.6 \mathrm{eV}$. The P3HT layer, however, does not contribute to the generation of photocurrent $[14,21]$. On the contrary, any photogeneration 
within the P3HT is known to have an adverse effect on $J_{\mathrm{SC}}$ and FF [14,21]. Lastly, the EQE of cells with $150 \mathrm{~nm}$ thick $\mathrm{Sb}_{2} \mathrm{~S}_{3}$ indicates a decline of the collection of photogenerated carriers in the 350-600 nm wavelength range (Figure $3 \mathrm{~b}$ ). The decrease is more drastic at lower wavelengths, which are more rapidly dampened in $\mathrm{Sb}_{2} \mathrm{~S}_{3}$, as evident from the absorption coefficient (Figure 3c), and related photoexcitation in the $\mathrm{Sb}_{2} \mathrm{~S}_{3}$ occurs closer to the side of incidence, i.e., the ETM/ $\mathrm{Sb}_{2} \mathrm{~S}_{3}$ interface. Hence, we are led to conclude that the holes photogenerated near the $\mathrm{ETM} / \mathrm{Sb}_{2} \mathrm{~S}_{3}$ interface, which must travel the farthest towards the HTM, face mobility issues when traversing the thickest $(150 \mathrm{~nm})$ absorber layer. On the other end, at wavelengths above $600 \mathrm{~nm}$, the benefit of using layers thicker than $100 \mathrm{~nm}$ to absorb more light is clearly seen through increased EQE, as expected. For reference, the penetration depth for light of $600 \mathrm{~nm}$ wavelength is about $100 \mathrm{~nm}$, assuming $\alpha=1 \times 10^{5} \mathrm{~cm}^{-1}$ (Figure 3c). Electron mobility tends to be greater in semiconductors when compared to hole mobility, although the efficacy of electron transport is also subject to change when the absorber thickness is varied. In this particular case, however, the spacer effect also occurs in the EQE spectra at wavelengths above $600 \mathrm{~nm}$, for which the light reaches deepest into $\mathrm{Sb}_{2} \mathrm{~S}_{3}$ and closer to the back electrode. Hence, more sophisticated analyses might be appropriate for the complete depiction of the impact of $\mathrm{Sb}_{2} \mathrm{~S}_{3}$ thickness on electron transport. The existence of the optical spacer effect can also have a negative impact. Even some tens of nanometers off of the optimum HTM thickness at constant absorber layer thickness could drastically decrease the $J_{\mathrm{SC}}$; thus it is crucial to ensure uniform thickness of P3HT throughout the whole area of the solar cell [62].

\section{Influence of cell area on PV performance of semitransparent $\mathrm{Sb}_{2} \mathrm{~S}_{3}$ solar cells}

To investigate the effect of enlarging cell area on PV performance, we fabricated cells with active area ranging from 1.7 to $180 \mathrm{~mm}^{2}$ and calculated the photoconversion parameters from $I-V$ curves measured at $100 \mathrm{~mW} \mathrm{~cm}^{-2}$ with AM1.5G (Figure 3d). The cross-sectional SEM view of the best solar cell with $100 \mathrm{~nm}$ of $\mathrm{Sb}_{2} \mathrm{~S}_{3}$ is presented in Figure 4 alongside the corresponding device schematic. As the cell area was increased from 1.7 to $180 \mathrm{~mm}^{2}, V_{\mathrm{OC}}, J_{\mathrm{SC}}, \mathrm{FF}$, and $R_{\mathrm{SH}}$ all decreased linearly at different rates, but at the same time, $R_{\mathrm{S}}$ increased substantially (Figure 5). As a result, the PCE decreased from

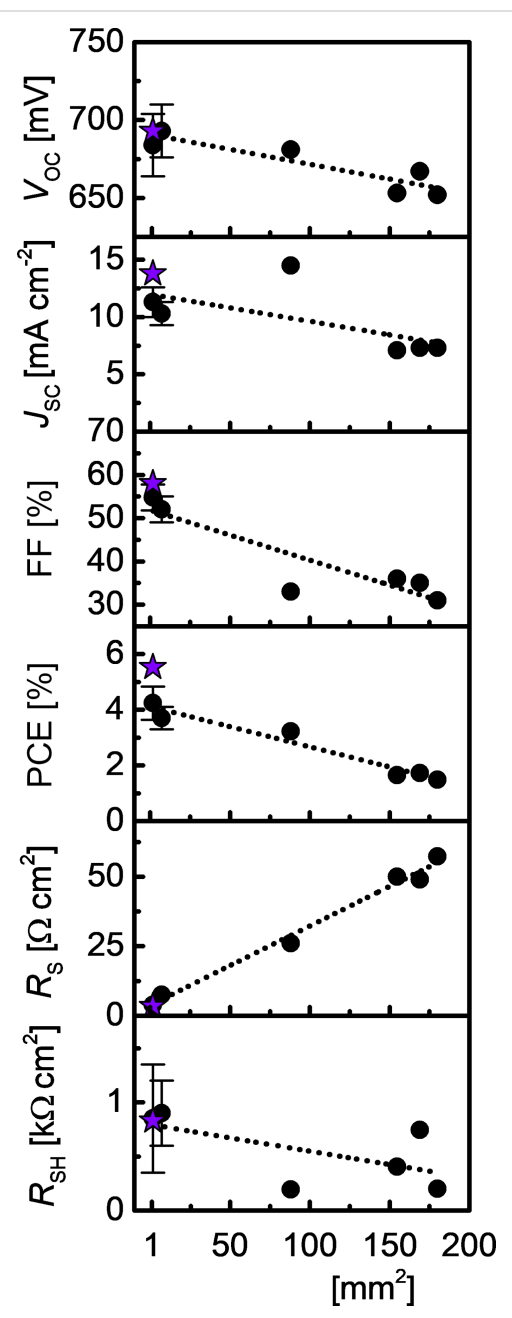

Figure 5: Photoconversion parameters of $100 \mathrm{~nm} \mathrm{Sb} \mathrm{S}_{3}$ solar cells under illumination at AM1.5G as a function of cell area. The dotted lines are a guide to the eye; the purple star signifies the best-performing $1.7 \mathrm{~mm}^{2}$ cell with $5.5 \%$ PCE. The vertical bars signify standard deviation, and black dots represent either average values of smaller cells (area $<10 \mathrm{~mm}^{2}$ ), or individual values of larger cells (area $>10 \mathrm{~mm}^{2}$ ).

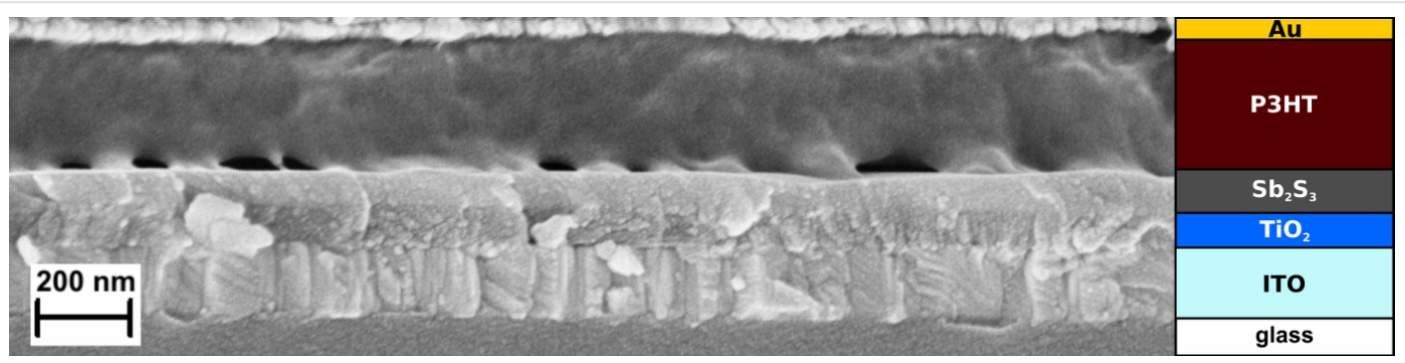

Figure 4: SEM cross-section of the best-performing 5.5\% PCE solar cell (100 nm Sb $\mathrm{S}_{3}$ ) and the corresponding device schematic. 
$4.2 \pm 0.6 \%$ to $1.6 \%$. The highest PCE of $5.5 \%, 4.7 \%$, and $3.2 \%$ at AM1.5G (Table 2) was obtained in the three best-performing cells with $1.7 \mathrm{~mm}^{2}, 7.1 \mathrm{~mm}^{2}$ and $88 \mathrm{~mm}^{2}$ area, respectively. The statistical variance of photoconversion parameters $\left(V_{\mathrm{OC}}\right.$, $\left.J_{\mathrm{SC}}, \mathrm{FF}, \mathrm{PCE}, R_{\mathrm{S}}, R_{\mathrm{SH}}\right)$ of 36 cells of $7.1 \mathrm{~mm}^{2}$ active area with $100 \mathrm{~nm} \mathrm{Sb}_{2} \mathrm{~S}_{3}$ is presented in Figure $\mathrm{S} 2$ in Supporting Information File 1.

Despite commendable $V_{\mathrm{OC}}(682 \mathrm{mV})$ and $J_{\mathrm{SC}}\left(14.5 \mathrm{~mA} \mathrm{~cm}{ }^{-2}\right)$, the FF is substantially smaller $(33 \%)$ in larger $\left(\approx 100 \mathrm{~mm}^{2}\right)$ cells when compared to $<10 \mathrm{~mm}^{2}$ cells (Table 2 ) due to about three times larger $R_{\mathrm{S}}\left(26 \Omega \mathrm{mm}^{2}\right)$ and about three times smaller $R_{\mathrm{SH}}$ $\left(190 \Omega \mathrm{mm}^{2}\right.$ ) under both illuminated (Figure $3 \mathrm{~d}$ ) and dark conditions (Figure S3 in the Supporting Information File 1). Also, the photocurrent loss in larger cells originates from the increase in $R_{\mathrm{S}}$ alongside the decrease in $R_{\mathrm{SH}}$ (Table 2). In addition, the probability of a given cell to exhibit photocurrent loss, and a resulting decrease in FF, increases proportionally with area due to unforeseen thickness fluctuations and a resultant mismatch in the thicknesses of $\mathrm{TiO}_{2}, \mathrm{Sb}_{2} \mathrm{~S}_{3}$, and P3HT layers, assuming to be primarily due to a uniform distribution of defects. Upon scribing large cells $\left(>100 \mathrm{~mm}^{2}\right)$ into several smaller $\approx 0.1 \mathrm{~mm}^{2}$ cells, all photoconversion parameters of the cells with USP-grown $\mathrm{Sb}_{2} \mathrm{~S}_{3}$ ended up showing values like those of individual cells with similar sizes, as has previously been demonstrated for structured ETA- $\mathrm{Sb}_{2} \mathrm{~S}_{3}$ cells [14]. In a study of $\mathrm{SnO}: \mathrm{F} / \mathrm{CdS} / \mathrm{Sb}_{2}(\mathrm{~S}, \mathrm{Se})_{3} / \mathrm{C} / \mathrm{Ag}$ solar cells of $20-80 \mathrm{~mm}^{2}$ area, a similar trend of lower PCE in larger cells was described (from $6.2 \%$ at $20 \mathrm{~mm}^{2}$ to $5.7 \%$ at $60 \mathrm{~mm}^{2}$ ) [64]. We perceive the most concerning issues with up-scaling of planar solar cells with $\mathrm{Sb}_{2} \mathrm{~S}_{3}$ grown by USP as the following: (1) enlarging the cell area causes FF loss, possibly because of minute, nontrivial discrepancies in layer thickness of $\mathrm{Sb}_{2} \mathrm{~S}_{3}$, and particularly P3HT; (2) enlarging the cell area introduces loss in $J_{\mathrm{SC}}$ and loss in FF due to the large resistivity of the absorber layer. It appears that the PCE on the level of small cells $\left(<10 \mathrm{~mm}^{2}\right)$ can only be achieved in larger cells $\left(>100 \mathrm{~mm}^{2}\right)$ if the $\mathrm{TiO}_{2}, \mathrm{Sb}_{2} \mathrm{~S}_{3}$ and $\mathrm{P} 3 \mathrm{HT}$ layers are uniform to the precision of a few nanometers in thickness $[14,21,34,62]$. Therefore, device performance is not only highly dependent on the deposition technique for its ability to produce pure phase $\mathrm{Sb}_{2} \mathrm{~S}_{3}$, but also on the capability of the specific deposition equipment to produce films with superior uniformity in thickness, i.e., nanometer precision, which USP can provide after some optimization.

\section{Influence of storage time on PV performance of semitransparent $\mathrm{Sb}_{2} \mathrm{~S}_{3}$ solar cells}

The stability of solar cells is paramount to ensure long-term performance under operation conditions, in turn maximizing return on investment. We investigated the stability of photoconversion parameters of cells of $7.1 \mathrm{~mm}^{2}$ and $88 \mathrm{~mm}^{2}$ area with USP-grown $\mathrm{Sb}_{2} \mathrm{~S}_{3}$ by keeping the cells at rest in $V_{\mathrm{OC}}$ condition for 230 days at room temperature (RT), relative humidity (RH) $<30 \%$, and exposed to both indoor light and daylight incident through the laboratory windows (Figure 6). In the $7.1 \mathrm{~mm}^{2}$ cell, over 230 days, $V_{\mathrm{OC}}$ increased slightly, whereas $J_{\mathrm{SC}}$ was halved, FF decreased slightly due to three times smaller $R_{\mathrm{SH}}$, and, as a result PCE was halved in the tested $7.1 \mathrm{~mm}^{2}$ cell (Figure 5, numeric data in Table S2 in the Supporting Information File 1), whereas $R_{\mathrm{S}}$ remained constant. In comparison, a trend of PCE decreasing from $3.7 \%$ to $1.5 \%$ after 300 days of aging was observed in ETA cells with a $\mathrm{TiO}_{2} / \mathrm{Sb}_{2} \mathrm{~S}_{3} / \mathrm{CuSCN}$ structure [24]. The $V_{\mathrm{OC}}$ of the $88 \mathrm{~mm}^{2}$ cell increased from $648 \mathrm{mV}$ to $682 \mathrm{mV}$ after 14 days (Figure 5), and remained constant after 363 days of storage, unlike the linear increase of $20 \mathrm{mV}$ per 100 days observed in the $7.1 \mathrm{~mm}^{2}$ cell. The reason for this discrepancy is still under question and requires further study. A partially reversible increase of $V_{\mathrm{OC}}$ over time due to humidity in air is common for solar cells containing organic materials [9]. $J_{\mathrm{SC}}$ declines linearly at a similar rate in both cells, $2.0 \mathrm{~mA} \mathrm{~cm}^{-2}$ per 100 days for the small cell, and $1.4 \mathrm{~mA} \mathrm{~cm}^{-2}$ per 100 days for the $88 \mathrm{~mm}^{2}$ cell, independent of the initial $J_{\mathrm{SC}}$ value. The linear decrease of $J_{\mathrm{SC}}$ during aging in light or dark conditions correlates with the general trend in organic PV [9], meaning the stability of $\mathrm{Sb}_{2} \mathrm{~S}_{3}$ hybrid solar cell hinges on the stability of the chosen HTM. The FF increased slightly in the $88 \mathrm{~mm}^{2}$ cell,

Table 2: Photoconversion parameters ${ }^{\mathrm{a}}$ of solar cells as a function of active area. The best results are given in parentheses.
\begin{tabular}{|llllllll} 
Area $\left[\mathrm{mm}^{2}\right]$ & $V_{\mathrm{OC}}[\mathrm{mV}]$ & $J_{\mathrm{SC}, I-V}\left[\mathrm{~mA} \mathrm{~cm}{ }^{-2}\right]$ & $\mathrm{FF}[\%]$ & $\mathrm{PCE}[\%]$ & $R_{\mathrm{S}}\left[\Omega \mathrm{cm}^{2}\right]$ & $R_{\mathrm{SH}}\left[\mathrm{k} \Omega \mathrm{cm}^{2}\right]$ & $\mathrm{Nr}^{\mathrm{b}}$ \\
\hline 1.7 & $684 \pm 20^{\mathrm{C}}$ & $11.3 \pm 1.3$ & $55 \pm 3$ & $4.3 \pm 0.6$ & $3.9 \pm 1.2$ & $0.8 \pm 0.5$ & 37 \\
& $(693)$ & $(13.8)$ & $(58)$ & $(5.53)$ & $(3.3)$ & $(0.8)$ & \\
7.1 & $693 \pm 17$ & $10.3 \pm 1.0$ & $52 \pm 3$ & $3.7 \pm 0.4$ & $7.6 \pm 1.5$ & $0.9 \pm 0.3$ & 36 \\
& $(726)$ & $(12.3)$ & $(52)$ & $(4.67)$ & $(5.9)$ & $(0.7)$ & 1 \\
88 & 681 & 14.5 & 33 & 3.22 & 26 & 0.2 & 1 \\
155 & 653 & 7.1 & 36 & 1.65 & 50 & 0.4 & 1 \\
169 & 667 & 7.3 & 35 & 1.72 & 49 & 0.8 & 1 \\
180 & 652 & 7.3 & 31 & 1.49 & 57 & 0.2 & 1 \\
\hline
\end{tabular}

aMeasurement conditions: $100 \mathrm{~mW} \mathrm{~cm}{ }^{-2}, \mathrm{AM} 1.5 \mathrm{G}, \mathrm{Sb}_{2} \mathrm{~S}_{3}$ thickness $100 \mathrm{~nm}$; ' Number of measured cells; ' $S$ tandard deviation. 


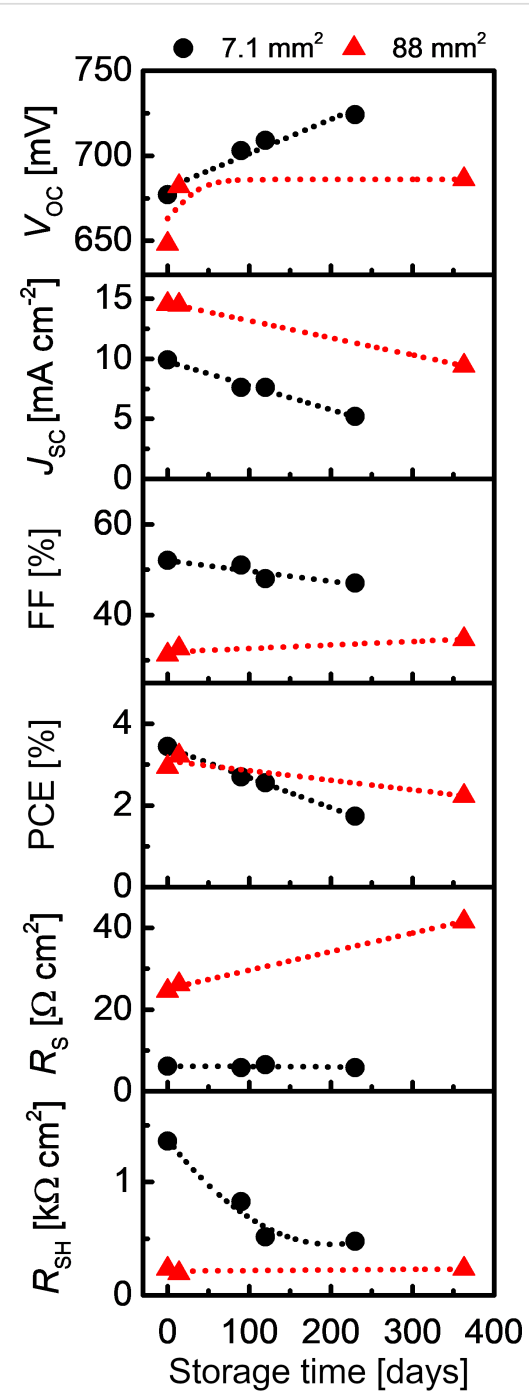

Figure 6: Photoconversion parameters of $\left(\approx 100 \mathrm{~nm} \mathrm{Sb}_{2} \mathrm{~S}_{3}\right)$ solar cells at $\mathrm{AM} 1.5 \mathrm{G}$ as a function of storage time. The dotted lines are a guide to the eye. Black circles refer to $7.1 \mathrm{~mm}^{2}$ cell area, and red triangles refer to $88 \mathrm{~mm}^{2}$ cell area. Samples composed of several small cells with P3HT only partially covered by Au were kept without any particular artificial conditions or encapsulation, and between measurements, were exposed to air and cycles of both indoor fluorescent tube irradiation and daylight for up to 363 days at $\approx 20{ }^{\circ} \mathrm{C}, \mathrm{RH}<30 \%$.

opposite to the slight decrease in the smaller cell. Consequently, the PCE of the larger cell decreases by $\approx 0.2 \%$ per 100 days, that is at a slower rate compared to the decrease of $0.7 \%$ per 100 days for the small cell. According to Hintz et al., the in-flux of moisture and oxygen from air presumably leads to degradation of P3HT [65]. We suppose that this process occurs more slowly in the larger cell, which could explain why the larger cell retains more PCE over time compared to the smaller cell. Another discrepancy appears when examining the $R_{\mathrm{S}}$ and $R_{\mathrm{SH}}$. The $R_{\mathrm{S}}$ of the large cell increases linearly by $4.5 \Omega \mathrm{cm}^{2}$ per 100 days, whereas $R_{\mathrm{S}}$ is constant for the small cell. The opposite occurs for $R_{\mathrm{SH}}$, where the small cell rapidly loses $R_{\mathrm{SH}}$ over the first 120 days, but the initial $R_{\mathrm{SH}}$ in the large cell is retained after one year. The decrease in PCE over time observed in both $7.1 \mathrm{~mm}^{2}$ and $88 \mathrm{~mm}^{2}$ area solar cells is probably due to moisture-assisted oxidation of P3HT [65]. Thus, to inhibit loss of PCE over time, encapsulation of the solar cell from moisture and oxygen is advised. Deng et al. studied the effect of storage time on the PCE of ITO/TiO $/$ as-deposited $\mathrm{Sb}_{2} \mathrm{~S}_{3} / \mathrm{P} 3 \mathrm{HT} / \mathrm{Au}$, and $\mathrm{ITO} / \mathrm{TiO}_{2} / \mathrm{Sb}_{2} \mathrm{~S}_{3}$ (Se-annealed)/Au solar cells under continuous illumination by measuring $J-V$ every $24 \mathrm{~h}$ [66]. The Se-annealed sample experienced a net gain in PCE in the first $24 \mathrm{~h}$, which was retained over 400 hours of illumination [66]. The sample containing P3HT lost all PCE after 150 hours of illumination, mainly because of the loss of $J_{\mathrm{SC}}$ [66]. In the same study, it was shown that solar cells without the P3HT layer, with both as-deposited and Se-annealed $\mathrm{Sb}_{2} \mathrm{~S}_{3}$ absorber, did not experience a quantifiable loss of PCE over six months of storage in air [66]. Assuming that the materials properties of the layers in these solar cells are similar to the corresponding layers in this study, we argue that the loss of PCE after storage in air is probably caused by the organic P3HT layer. In conclusion, we have demonstrated that increasing the active area of the cell helps to retain PCE of the solar cell based on USP-grown $\mathrm{Sb}_{2} \mathrm{~S}_{3}$ absorber over extended periods of time, and this dependence on cell area certainly warrants more thorough investigation.

\section{Influence of light intensity on PV performance of semitransparent $\mathrm{Sb}_{2} \mathrm{~S}_{3}$ solar cells}

The intensity of incident light in real working conditions of solar cells is not constant and is rarely at standard brightness, requiring solar cells to perform well at standard light intensity as well as at attenuated light intensities. In addition, close inspection of the dependence of photoconversion parameters on light intensity could provide valuable information about the cause of $J_{\mathrm{SC}}$ and FF losses in the solar cell [47]. We investigated the $I-V$ output of cells with a USP-grown $\mathrm{Sb}_{2} \mathrm{~S}_{3}$ absorber at a number of different illumination intensities between 3 and $100 \mathrm{~mW} \mathrm{~cm}^{-2}$. A constant device temperature was maintained to avoid introduction of additional uncertainty to the measurements. The light intensity was attenuated by using metal mesh gray filters. By decreasing the incident light intensity from 100 to $3 \mathrm{~mW} \mathrm{~cm}^{-2}, V_{\mathrm{OC}}$ and $J_{\mathrm{SC}}$ decreased, as expected, whereas $R_{\mathrm{SH}}, R_{\mathrm{S}}$ and FF increased (Figure 7). Overall, the PCE increased from $3.9 \%$ at $100 \mathrm{~mW} \mathrm{~cm}{ }^{-2}$, AM1.5G, to over $10 \%$ at $3 \mathrm{~mW} \mathrm{~cm}^{-2}$. The increase in PCE when lowering light intensity is hereby taken as characteristic of $\mathrm{Sb}_{2} \mathrm{~S}_{3}$-based solar cells $[19,47]$. Curiously, the tendency of change in PCE for $\mathrm{Sb}_{2} \mathrm{~S}_{3}$ solar cells is opposite to that of monocrystalline Si solar cells at lower light intensity [67]. In comparison, after aging a solar cell under ambient light and RT for 180 days, in the same conditions as in the storage time test (Figure 5), the PV parameters follow similar trends depending on light intensity (Figure 6). 


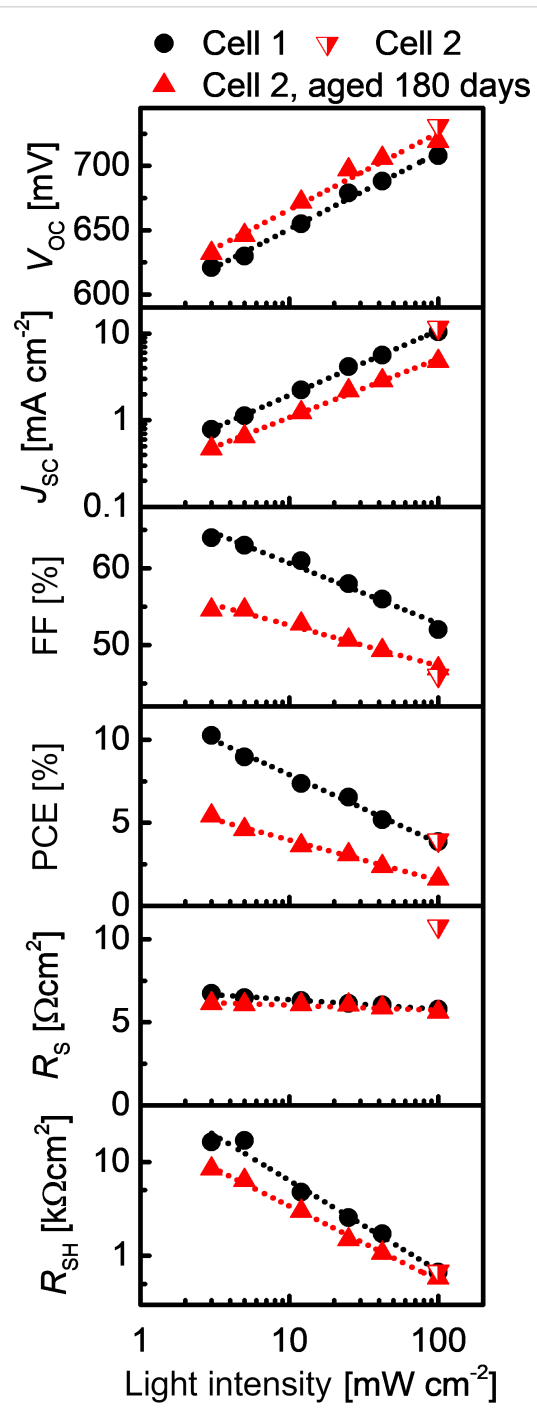

Figure 7: Photoconversion parameters of $100 \mathrm{~nm} \mathrm{Sb}_{2} \mathrm{~S}_{3}$ solar cells without aging (black dots) or after 180 days of aging (red triangles) as a function of light intensity. The dotted lines are a guide to the eye. The light intensity was attenuated from AM1.5G, $100 \mathrm{~mW} \mathrm{~cm}^{-2}$ with the use of metal mesh gray filters.

The elevated PCE in freshly prepared and aged cells with USPgrown $\mathrm{Sb}_{2} \mathrm{~S}_{3}$ is related to an associable gain of FF and $R_{\mathrm{SH}}$ at decreased light intensity. The exact reasons for this dependence are yet to be clarified. An investigation on the low light intensity behavior of $\mathrm{Cu}$ - and $\mathrm{Se}$-doped $\mathrm{Sb}_{2} \mathrm{~S}_{3}$-based hybrid solar cells showed that the PCE of these cells was also significantly higher at lower light intensity $\left(2.12 \%\right.$ at $25 \mathrm{~mW} \mathrm{~cm}^{-2}$ and $9.03 \%$ at $5 \mathrm{~mW} \mathrm{~cm}{ }^{-2}$ ), and it was concluded that the behavior was similar to amorphous $\mathrm{Si}$ solar cells [68]. In the case of amorphous $\mathrm{Si}$ solar cells, the decrease in FF at increasing light intensity was connected to the increasing electric field inside the solar cell [69]. Essentially, if the quality of the solar cell is improved, the PCE at higher light intensity will increase and approach the PCE at low light intensity [69]. While the explanations for many phenomena in this structure are still under discussion, inorganic ETM/ $\mathrm{Sb}_{2} \mathrm{~S}_{3}$ /organic HTM solar cells demonstrate excellent applicability for $1-10 \mathrm{~mW} \mathrm{~cm}^{-2}$ light harvesting, a commonly observed range of light intensity when partial or full cloud cover is present. The durability of these solar cells is expected to be a manageable concern under attenuated light.

\section{Conclusion}

Semitransparent and oxide-free thin films of crystalline $\mathrm{Sb}_{2} \mathrm{~S}_{3}$ were fabricated at low temperature using two steps, an initial non-vacuum growth by facile spray pyrolysis (USP) at $200{ }^{\circ} \mathrm{C}$, followed by a low-temperature annealing in a non-oxygen containing environment at $170{ }^{\circ} \mathrm{C}$. This process is compatible with existing window glass manufacturing technology. By integrating semitransparent thin films of $\mathrm{Sb}_{2} \mathrm{~S}_{3}$ with optimized thickness of $100 \mathrm{~nm}$ in the planar ITO/ $\mathrm{TiO}_{2} / \mathrm{Sb}_{2} \mathrm{~S}_{3} / \mathrm{P} 3 \mathrm{HT} / \mathrm{Au}$ hybrid solar cell, a PCE of $5.5 \%$ and an AVT of $26 \%$ in ITO/ $\mathrm{TiO}_{2} / \mathrm{Sb}_{2} \mathrm{~S}_{3}$ were achieved. The PCE and AVT combinations obtained in this study are similar to those reported for other semitransparent thin film solar cell configurations. The feasibility of fabricating large-area lab-scale $\mathrm{Sb}_{2} \mathrm{~S}_{3}$ solar cells by the USP method is demonstrated by achieving a PCE of $3.2 \%$ at $88 \mathrm{~mm}^{2}$ solar cell area, laying the foundation for further improvements in scalability. Furthermore, over the span of a year, the $88 \mathrm{~mm}^{2}$ non-encapsulated solar cell stored under standard office conditions showed half the rate of aging and an increased stability towards humidity and air when compared to smaller cells $\left(<10 \mathrm{~mm}^{2}\right.$ area). We consider the trend of increased PCE at decreased light intensity observed in USP-Sb ${ }_{2} \mathrm{~S}_{3}$ solar cells favorable for light conversion under cloud cover. It is clear that the key to further increase the efficiency, area-scalability, and durability of opaque and semitransparent $\mathrm{Sb}_{2} \mathrm{~S}_{3}$ solar cells lies in tuning of the layers and interfaces of the ETM/ $\mathrm{Sb}_{2} \mathrm{~S}_{3} /$ HTM stack. Considering the potential benefits of the capability of USP for large-scale production, extensive costsavings could be achieved by depositing all component layers in the $\mathrm{Sb}_{2} \mathrm{~S}_{3}$-solar cell by ultrasonic spray pyrolysis, further accentuating facile integration in solar window glass production.

\section{Experimental \\ Solar cell fabrication}

All chemicals were sourced from Sigma-Aldrich and used as-purchased without further processing. ITO covered (25 $\Omega \mathrm{sq}^{-1}, \mathrm{ZSW}$ ) soda-lime glass substrates were cleaned with deionized water, ethanol, deionized water, $\mathrm{H}_{2} \mathrm{SO}_{4}(1 \% \mathrm{w} / \mathrm{w})$, and rinsed with deionized water before drying at $105{ }^{\circ} \mathrm{C}$ in air. Then, a dense, compact $\mathrm{TiO}_{2}$ layer was grown on glass/ITO by ultrasonic spray pyrolysis in air from $0.1 \mathrm{M}$ titanium tetraisopropoxide $(98 \% \mathrm{v} / \mathrm{v})$ and $0.4 \mathrm{M}$ acetylacetone $(99 \% \mathrm{v} / \mathrm{v})$ dissolved in ethanol $(96.6 \% \mathrm{v} / \mathrm{v})$ according to a previously published procedure $[28,46,70]$. After deposition, the glass/ 
$\mathrm{ITO} / \mathrm{TiO}_{2}$ stack was annealed at $450{ }^{\circ} \mathrm{C}$ for $30 \mathrm{~min}$ in air to form anatase.

Amorphous layers of $\mathrm{Sb}_{2} \mathrm{~S}_{3}$ were deposited by ultrasonic spray pyrolysis in air from a solution of $\mathrm{SbCl}_{3}(99 \% \mathrm{w} / \mathrm{w})$ and $\mathrm{SC}\left(\mathrm{NH}_{2}\right)_{2}(98 \% \mathrm{w} / \mathrm{w}), \mathrm{Sb} / \mathrm{S}$ molar ratio 1:3, dissolved in methanol $(99.8 \% \mathrm{v} / \mathrm{v})$, according to a previously published procedure [46]. The $\mathrm{Sb}_{2} \mathrm{~S}_{3}$ thin film thickness was controlled by varying the concentration of $\mathrm{SbCl}_{3}$ and $\mathrm{SC}\left(\mathrm{NH}_{2}\right)_{2}(1: 3)$ in methanol. The $\mathrm{Sb}_{2} \mathrm{~S}_{3}$ thin films were crystallized by annealing in vacuum $\left(\leq 4 \times 10^{-6}\right.$ torr) at $170{ }^{\circ} \mathrm{C}$ for $5 \mathrm{~min}$.

We observed that without annealing of $\mathrm{Sb}_{2} \mathrm{~S}_{3}$, the solar cells of the same structure showed a $V_{\mathrm{OC}}$ of about $700 \mathrm{mV}$, but virtually no $J_{\mathrm{SC}}$, producing PCE $<0.1 \%$. All solar cells henceforth were based on annealed $\mathrm{Sb}_{2} \mathrm{~S}_{3}$ thin films.

P3HT, as the hole transport material (HTM), was applied by immersing samples into a room-temperature solution of regioregular P3HT $(2 \% \mathrm{w} / \mathrm{w})$ dissolved in chlorobenzene $(99.5 \% \mathrm{v} / \mathrm{v})$, then dried at $50{ }^{\circ} \mathrm{C}$ for $10 \mathrm{~min}$ in air, and further dried in vacuum $\left(\leq 4 \times 10^{-6}\right.$ torr) for $5 \mathrm{~min}$. The solar cells were completed by depositing the Au counter electrode by thermal evaporation in vacuum $\left(<2 \times 10^{-4}\right.$ torr $)$. The cells with areas of $1.7 \mathrm{~mm}^{2}$ and $7.1 \mathrm{~mm}^{2}$ were prepared with the use of perforated metal masks. The area of cells larger than $7.1 \mathrm{~mm}^{2}$ was defined by mechanically scribing contacts after Au deposition.

\section{Thin film characterization}

The characterization methods employed in this study, except for XRD and XES, have already been described in detail elsewhere [28]. The structure and phase composition were characterized by XRD (Rigaku Ultima IV, $\theta-2 \theta, \mathrm{Cu} \mathrm{K} \alpha_{1} \lambda=1.5406 \AA$, $40 \mathrm{kV}$, $40 \mathrm{~mA}$, step $0.02^{\circ}, 5^{\circ} \mathrm{min}^{-1}$, Si strip detector D/teX Ultra) and Raman spectroscopy (Horiba Labram HR 800, backscattering mode, $\approx 143 \mu \mathrm{W} \mu \mathrm{m}^{-2}$ ). The elemental composition of glass/ $\mathrm{ITO} / \mathrm{TiO}_{2} / \mathrm{Sb}_{2} \mathrm{~S}_{3}$ samples and solar cell cross sections were recorded in the combined energy dispersive X-ray spectrometer (Bruker spectrometer, ESPRIT 1.8, $7 \mathrm{kV}$ ) and scanning electron microscope (Zeiss HR FESEM Ultra 55, $4 \mathrm{kV}$ ) system. The surface morphology of glass/ITO/ $/ \mathrm{TiO}_{2} / \mathrm{Sb}_{2} \mathrm{~S}_{3}$ samples was recorded in a HR-SEM (Helios NanoLab 600, FEI Company). The optical properties were measured using a UV-vis-NIR spectrophotometer (Jasco V-670, integrating sphere, air reference). The AVT was calculated as the arithmetic average of total transmittance of the glass/ITO/TiO $2 / \mathrm{Sb}_{2} \mathrm{~S}_{3}$ stack in the 380-740 nm wavelength range by using Equation 1 [71]:

$$
\operatorname{AVT}(\%)=\frac{\int_{380}^{740} T(\lambda) \mathrm{d}(\lambda)}{740-380} \text {, }
$$

where $\lambda$ is the wavelength, and $T(\lambda)(\%)$ is the total transmittance at $\lambda$. The resistivity of $\mathrm{Sb}_{2} \mathrm{~S}_{3}$ layers on glass/ $/ \mathrm{TiO}_{2}$ substrate was measured at room temperature in dark by using the van der Pauw technique (MMR Technologies H50) and collinear four-wire $I-V$ sensing (Eco Chemie BV, AutoLab PGSTAT302). The contact material for both measurements was deposited from an aqueous graphite ink from Alfa Aesar. $\mathrm{S} \mathrm{L}_{2,3}$ soft X-ray emission spectra of $\mathrm{Sb}_{2} \mathrm{~S}_{3}$ were measured using the SALSA endstation [72], at the open port of Beamline 8.0.1 of the Advanced Light Source (ALS), at Lawrence Berkeley National Laboratory (LBNL). The $\mathrm{Sb}_{2} \mathrm{~S}_{3}$ films were excited with a photon energy of $180 \mathrm{eV}$, and the emitted X-rays at the $\mathrm{S} \mathrm{L}_{2,3}$ edge were recorded as a function of energy. The reference chemicals for XES measurements were purchased from Alfa Aesar $\left(\mathrm{Sb}_{2} \mathrm{~S}_{3}\right.$ and $\mathrm{Sb}_{2} \mathrm{O}_{3}$ powders, both $\left.99.999 \% \mathrm{w} / \mathrm{w}\right)$ and $\mathrm{Sb}_{2}\left(\mathrm{SO}_{4}\right)_{3}$ powder $(99.91 \% \mathrm{w} / \mathrm{w})$ from Chemsavers.

\section{Solar cell characterization}

The current-voltage $(I-V)$ curves of the solar cells were measured by using a factory-calibrated solar simulator (Newport Oriel Sol3A class AAA) that provided AM1.5G, $100 \mathrm{~mA} \mathrm{~cm}^{-2}$ light intensity, a metal mask with adjustable aperture area, and a source meter. The light intensity was regulated for the light intensity dependence measurements using gray filters (metal meshes with varied hole size). The external quantum efficiency (EQE) spectra were measured using a monochromatized light source (Newport 300 W Xenon lamp, 69911 with a monochromator Newport Cornerstone 260), a digital lock-in detector (Merlin) and a factory-calibrated Si reference detector. The integrated short-circuit current density $\left(J_{\mathrm{SC}}\right)$ from EQE was calculated in AM1.5G conditions with the online tool Open Photovoltaics Analysis Platform and compared with the $J_{\mathrm{SC}}$ obtained from the $I-V$ measurements.

\section{Supporting Information}

Additional literature data of $\mathrm{Sb}_{2} \mathrm{~S}_{3}$ solar cells, EDX data, statistical data of PV parameters of the optimized solar cell, dark $J-V$ scans, and numeric data of the solar cell aging experiment.

\section{Supporting Information File 1}

Additional data.

[https://www.beilstein-journals.org/bjnano/content/ supplementary/2190-4286-10-230-S1.pdf]

\section{Acknowledgements}

The authors thank Dr. Valdek Mikli from the Laboratory of Optoelectronic Materials Physics at Tallinn University of Technology (TUT) for recording the cross-section SEM image of the 
solar cell and for EDX measurements, and Eng. Jekaterina Kozlova from the Institute of Physics at Tartu University for recording surface SEM images of glass/ITO/TiO $/ \mathrm{Sb}_{2} \mathrm{~S}_{3}$ samples. For valuable discussions, J. S. E. thanks Dr. Arvo Mere from the Department of Cybernetics and Dr. Nicolae Spalatu from the Laboratory of Thin Film Chemical Technologies (TUT).

\section{Funding}

This work was supported by the Estonian Research Council project IUT19-4 "Thin films and nanomaterials by wet-chemical methods for next-generation photovoltaics" and European Regional Development Fund project TK141 (TAR16016EK) "Advanced materials and high-technology devices for energy recuperation systems". This research used resources of the Advanced Light Source, which is a DOE Office of Science User Facility under contract no. DE-AC02-05CH11231. The BalticAmerican Freedom Foundation (BAFF) is acknowledged for a personal research grant of E. K. at the University of Nevada, Las Vegas.

\section{ORCID ${ }^{\circledR}$ iDs}

Jako S. Eensalu - https://orcid.org/0000-0002-4312-0227

Atanas Katerski - https://orcid.org/0000-0003-1980-3391

Wanli Yang - https://orcid.org/0000-0003-0666-8063

\section{References}

1. Husain, A. A. F.; Hasan, W. Z. W.; Shafie, S.; Hamidon, M. N.; Pandey, S. S. Renewable Sustainable Energy Rev. 2018, 94, 779-791. doi:10.1016/j.rser.2018.06.031

2. Dubey, S.; Sarvaiya, J. N.; Seshadri, B. Energy Procedia 2013, 33, 311-321. doi:10.1016/j.egypro.2013.05.072

3. van Dyk, E. E.; Meyer, E. L.; Leitch, A. W. R.; Scott, B. J. S. Afr. J. Sci. 2000, 96, 198-200.

4. Shin, D.; Choi, S.-H. Coatings 2018, 8, 329-358. doi:10.3390/coatings8100329

5. Ito, S.; Chen, P.; Comte, P.; Nazeeruddin, M. K.; Liska, P.; Péchy, P.; Grätzel, M. Prog. Photovoltaics 2007, 15, 603-612. doi:10.1002/pip.768

6. Chen, K.-S.; Salinas, J.-F.; Yip, H.-L.; Huo, L.; Hou, J.; Jen, A. K.-Y. Energy Environ. Sci. 2012, 5, 9551-9557. doi:10.1039/c2ee22623e

7. Roldán-Carmona, C.; Malinkiewicz, O.; Betancur, R.; Longo, G.; Momblona, C.; Jaramillo, F.; Camacho, L.; Bolink, H. J. Energy Environ. Sci. 2014, 7, 2968-2973. doi:10.1039/c4ee01389a

8. Wang, D.; Wright, M.; Elumalai, N. K.; Uddin, A. Sol. Energy Mater. Sol. Cells 2016, 147, 255-275. doi:10.1016/j.solmat.2015.12.025

9. Jørgensen, M.; Norrman, K.; Gevorgyan, S. A.; Tromholt, T.; Andreasen, B.; Krebs, F. C. Adv. Mater. (Weinheim, Ger.) 2012, 24 , 580-612. doi:10.1002/adma.201104187

10. Bristow, N.; Kettle, J. Sol. Energy Mater. Sol. Cells 2018, 175, 52-59. doi:10.1016/j.solmat.2017.10.008

11. Correa-Baena, J.-P.; Saliba, M.; Buonassisi, T.; Grätzel, M.; Abate, A.; Tress, W.; Hagfeldt, A. Science 2017, 358, 739-744. doi:10.1126/science.aam6323
12. Greenwood, N. N.; Earnshaw, A. Chemistry of the Elements, 2nd ed.; Applied Organometallic Chemistry, Vol. 12; Butterworth-Heinemann: Oxford, United Kingdom, 1997.

13. Versavel, M. Y.; Haber, J. A. Thin Solid Films 2007, 515, 7171-7176. doi:10.1016/j.tsf.2007.03.043

14. Kondrotas, R.; Chen, C.; Tang, J. Joule 2018, 2, 857-878. doi:10.1016/j.joule.2018.04.003

15. Rajpure, K. Y.; Bhosale, C. H. Mater. Chem. Phys. 2000, 63, 263-269. doi:10.1016/s0254-0584(99)00233-3

16. Escorcia-García, J.; Becerra, D.; Nair, M. T. S.; Nair, P. K. Thin Solid Films 2014, 569, 28-34. doi:10.1016/j.tsf.2014.08.024

17. Parize, R.; Katerski, A.; Gromyko, I.; Rapenne, L.; Roussel, H.; Kärber, E.; Appert, E.; Krunks, M.; Consonni, V. J. Phys. Chem. C 2017, 121, 9672-9680. doi:10.1021/acs.jpcc.7b00178

18. Kim, D.-H.; Lee, S.-J.; Park, M. S.; Kang, J.-K.; Heo, J. H.; Im, S. H.; Sung, S.-J. Nanoscale 2014, 6, 14549-14554. doi:10.1039/c4nr04148h 19. Itzhaik, Y.; Niitsoo, O.; Page, M.; Hodes, G. J. Phys. Chem. C 2009, 113, 4254-4256. doi:10.1021/jp900302b

20. Choi, Y. C.; Lee, D. U.; Noh, J. H.; Kim, E. K.; Seok, S. I. Adv. Funct. Mater. 2014, 24, 3587-3592. doi:10.1002/adfm.201304238

21. Zimmermann, E.; Pfadler, T.; Kalb, J.; Dorman, J. A.; Sommer, D.; Hahn, G.; Weickert, J.; Schmidt-Mende, L. Adv. Sci. 2015, 2, 1500059. doi:10.1002/advs.201500059

22. Kim, J. K.; Veerappan, G.; Heo, N.; Wang, D. H.; Park, J. H. J. Phys. Chem. C 2014, 118, 22672-22677. doi:10.1021/jp507652r

23. Rodriguez-Lazcano, Y.; Nair, M. T. S.; Nair, P. K. J. Electrochem. Soc. 2005, 152, G635-G638. doi:10.1149/1.1945387

24. Nezu, S.; Larramona, G.; Choné, C.; Jacob, A.; Delatouche, B.; Péré, D.; Moisan, C. J. Phys. Chem. C 2010, 114, 6854-6859. doi:10.1021/jp100401e

25. Reeja-Jayan, B.; Manthiram, A. RSC Adv. 2013, 3, 5412-5421. doi:10.1039/c3ra23055d

26. Christians, J. A.; Kamat, P. V. ACS Nano 2013, 7, 7967-7974. doi:10.1021/nn403058f

27. You, M. S.; Lim, C.-S.; Kwon, D. H.; Heo, J. H.; Im, S. H.; Chae, K. J. Org. Electron. 2015, 21, 155-159. doi:10.1016/j.orgel.2015.02.015

28. Kärber, E.; Katerski, A.; Oja Acik, I.; Mere, A.; Mikli, V.; Krunks, M. Beilstein J. Nanotechnol. 2016, 7, 1662-1673. doi:10.3762/bjnano.7.158

29. Lan, C.; Liang, G.; Lan, H.; Peng, H.; Su, Z.; Zhang, D.; Sun, H.; Luo, J.; Fan, P. Phys. Status Solidi RRL 2018, 12, 1800025. doi:10.1002/pssr.201800025

30. Ye, Q.; Xu, Y.; Chen, W.; Yang, S.; Zhu, J.; Weng, J. Appl. Surf. Sci. 2018, 440, 294-299. doi:10.1016/j.apsusc.2018.01.090

31. Kaienburg, P.; Klingebiel, B.; Kirchartz, T. Beilstein J. Nanotechnol. 2018, 9, 2114-2124. doi:10.3762/bjnano.9.200

32. Wang, X.; Li, J.; Liu, W.; Yang, S.; Zhu, C.; Chen, T. Nanoscale 2017, 9, 3386-3390. doi:10.1039/c7nr00154a

33. Lei, H.; Yang, G.; Guo, Y.; Xiong, L.; Qin, P.; Dai, X.; Zheng, X.; Ke, W.; Tao, H.; Chen, Z.; Li, B.; Fang, G. Phys. Chem. Chem. Phys. 2016, 18, 16436-16443. doi:10.1039/c6cp02072k

34. Liu, C. P.; Wang, H. E.; Ng, T. W.; Chen, Z. H.; Zhang, W. F.; Yan, C.; Tang, Y. B.; Bello, I.; Martinu, L.; Zhang, W. J.; Jha, S. K. Phys. Status Solidi B 2012, 249, 627-633. doi:10.1002/pssb.201147393

35. Wang, W.; Strössner, F.; Zimmermann, E.; Schmidt-Mende, L. Sol. Energy Mater. Sol. Cells 2017, 172, 335-340. doi:10.1016/j.solmat.2017.07.046 
36. Jin, X.; Yuan, Y.; Jiang, C.; Ju, H.; Jiang, G.; Liu, W.; Zhu, C.; Chen, T. Sol. Energy Mater. Sol. Cells 2018, 185, 542-548. doi:10.1016/j.solmat.2018.06.017

37. Zhang, L.; Jiang, C.; Wu, C.; Ju, H.; Jiang, G.; Liu, W.; Zhu, C.; Chen, T. ACS Appl. Mater. Interfaces 2018, 10, 27098-27105. doi:10.1021/acsami.8b09843

38. Darga, A.; Mencaraglia, D.; Longeaud, C.; Savenije, T. J.; O’Regan, B.; Bourdais, S.; Muto, T.; Delatouche, B.; Dennler, G. J. Phys. Chem. C 2013, 117, 20525-20530. doi:10.1021/jp4072394

39. Tang, R.; Wang, X.; Jiang, C.; Li, S.; Liu, W.; Ju, H.; Yang, S.; Zhu, C.; Chen, T. ACS Appl. Mater. Interfaces 2018, 10, 30314-30321. doi:10.1021/acsami.8b08965

40. Zhang, L.; Wu, C.; Liu, W.; Yang, S.; Wang, M.; Chen, T.; Zhu, C. J. Mater. Chem. A 2018, 6, 21320-21326. doi:10.1039/c8ta08296k

41. Jiang, C.; Tang, R.; Wang, X.; Ju, H.; Chen, G.; Chen, T. Sol. RRL 2019, 3, 1800272. doi:10.1002/solr.201800272

42. Carlé, J. E.; Helgesen, M.; Hagemann, O.; Hösel, M.; Heckler, I. M.; Bundgaard, E.; Gevorgyan, S. A.; Søndergaard, R. R.; Jørgensen, M.; García-Valverde, R.; Chaouki-Almagro, S.; Villarejo, J. A.; Krebs, F. C. Joule 2017, 1, 274-289. doi:10.1016/j.joule.2017.08.002

43. Patil, P. S. Mater. Chem. Phys. 1999, 59, 185-198. doi:10.1016/s0254-0584(99)00049-8

44. López lbáñez, R.; Martín, F.; Ramos-Barrado, J. R.; Leinen, D. Surf. Coat. Technol. 2008, 202, 2408-2412. doi:10.1016/j.surfcoat.2007.09.016

45. Cheng, J.; Hu, R.; Wang, K.; Meng, X.; Li, Y.; Yang, X.; Liao, X.; Li, L.; Chong, K. B. Sol. RRL 2019, 3, 1800346. doi:10.1002/solr.201800346

46. Eensalu, J. S.; Katerski, A.; Kärber, E.; Oja Acik, I.; Mere, A.; Krunks, M. Beilstein J. Nanotechnol. 2019, 10, 198-210. doi:10.3762/bjnano.10.18

47. Moon, S.-J.; Itzhaik, Y.; Yum, J.-H.; Zakeeruddin, S. M.; Hodes, G.; Grätzel, M. J. Phys. Chem. Lett. 2010, 1, 1524-1527. doi:10.1021/jz100308q

48. Medina-Montes, M. I.; Montiel-González, Z.; Paraguay-Delgado, F.; Mathews, N. R.; Mathew, X. J. Mater. Sci.: Mater. Electron. 2016, 27 9710-9719. doi:10.1007/s10854-016-5033-0

49. Parize, R.; Cossuet, T.; Chaix-Pluchery, O.; Roussel, H.; Appert, E.; Consonni, V. Mater. Des. 2017, 121, 1-10. doi:10.1016/j.matdes.2017.02.034

50. Heske, C.; Groh, U.; Fuchs, O.; Umbach, E.; Franco, N.; Bostedt, C.; Terminello, L. J.; Perera, R. C. C.; Hallmeier, K. H.; Preobrajenski, A.; Szargan, R.; Zweigart, S.; Riedl, W.; Karg, F. Phys. Status Solidi A 2001, 187, 13-24. doi:10.1002/1521-396x(200109)187:1<13::aid-pssa13>3.0.co;2-d

51. Weinhardt, L.; Gleim, T.; Fuchs, O.; Heske, C.; Umbach, E.; Bär, M.; Muffler, H.-J.; Fischer, C.-H.; Lux-Steiner, M. C.; Zubavichus, Y.; Niesen, T. P.; Karg, F. Appl. Phys. Lett. 2003, 82, 571-573. doi:10.1063/1.1539553

52. Weinhardt, L.; Fuchs, O.; Peter, A.; Umbach, E.; Heske, C.; Reichardt, J.; Bär, M.; Lauermann, I.; Kötschau, I.; Grimm, A.; Sokoll, S.; Lux-Steiner, M. C.; Niesen, T. P.; Visbeck, S.; Karg, F. J. Chem. Phys. 2006, 124, 074705. doi:10.1063/1.2168443

53. Duncan, D. A.; Kephart, J. M.; Horsley, K.; Blum, M.; Mezher, M.; Weinhardt, L.; Häming, M.; Wilks, R. G.; Hofmann, T.; Yang, W.; Bär, M.; Sampath, W. S.; Heske, C. ACS Appl. Mater. Interfaces 2015, 7, 16382-16386. doi:10.1021/acsami.5b03503

54. Center for X-ray Optics (CXRO), Lawrence Berkeley National Laborato ry. X-Ray Attenuation Length. http://henke.lbl.gov/optical_constants/atten2.html (accessed Jan 15, 2019).
55. Bär, M.; Schubert, B.-A.; Marsen, B.; Wilks, R. G.; Blum, M.; Krause, S.; Pookpanratana, S.; Zhang, Y.; Unold, T.; Yang, W.; Weinhardt, L.; Heske, C.; Schock, H.-W. J. Mater. Res. 2012, 27, 1097-1104. doi:10.1557/jmr.2012.59

56. Koc, H.; Mamedov, A. M.; Deligoz, E.; Ozisik, H. Solid State Sci. 2012, 14, 1211-1220. doi:10.1016/j.solidstatesciences.2012.06.003

57. Lokhande, C. D.; Sankapal, B. R.; Mane, R. S.; Pathan, H. M.; Muller, M.; Giersig, M.; Ganesan, V. Appl. Surf. Sci. 2002, 193, 1-10. doi:10.1016/s0169-4332(01)00819-4

58. Krishnan, B.; Arato, A.; Cardenas, E.; Roy, T. K. D.; Castillo, G. A. Appl. Surf. Sci. 2008, 254, 3200-3206. doi:10.1016/j.apsusc.2007.10.098

59. Wedemeyer, H.; Michels, J.; Chmielowski, R.; Bourdais, S.; Muto, T.; Sugiura, M.; Dennler, G.; Bachmann, J. Energy Environ. Sci. 2013, 6, 67-71. doi:10.1039/c2ee23205g

60. Jo, H.-J.; Kim, S. H.; Kim, J. S.; Lee, S.-J.; Kim, D.-H. J. Korean Phys. Soc. 2016, 69, 541-546. doi:10.3938/jkps.69.541

61. Servaites, J. D.; Yeganeh, S.; Marks, T. J.; Ratner, M. A. Adv. Funct. Mater. 2010, 20, 97-104. doi:10.1002/adfm.200901107

62. Andersen, P. D.; Skårhøj, J. C.; Andreasen, J. W.; Krebs, F. C. Opt. Mater. 2009, 31, 1007-1012. doi:10.1016/j.optmat.2008.11.014

63. Georgitzikis, E.; Malinowski, P. E.; Maes, J.; Hadipour, A.; Hens, Z.; Heremans, P.; Cheyns, D. Adv. Funct. Mater. 2018, 28, 1804502. doi:10.1002/adfm.201804502

64. De Bray Sánchez, F.; Nair, M. T. S.; Nair, P. K. Appl. Surf. Sci. 2018, 454, 305-312. doi:10.1016/j.apsusc.2018.05.076

65. Hintz, H.; Egelhaaf, H.-J.; Lüer, L.; Hauch, J.; Peisert, H.; Chasse, T. Chem. Mater. 2011, 23, 145-154. doi:10.1021/cm102373k

66. Deng, H.; Yuan, S.; Yang, X.; Cai, F.; Hu, C.; Qiao, K.; Zhang, J.; Tang, J.; Song, H.; He, Z. Mater. Today Energy 2017, 3, 15-23. doi:10.1016/j.mtener.2017.02.001

67. Gong, C.; Posthuma, N.; Dross, F.; Kerschaver, E. V.; Giovanni, F.; Beaucarne, G.; Poortmans, J.; Hoofman, R. J. O. M. Comparison of nand $p$-type high efficiency silicon solar cell performance under low illumination conditions. In 2008 33rd IEEE Photovoltaic Specialists Conference, 2008; pp 1-4. doi:10.1109/pvsc.2008.4922441

68. Janošević, V.; Mitrić, M.; Bundaleski, N.; Rakočević, Z.; Validžić, I. L. Prog. Photovoltaics 2016, 24, 704-715. doi:10.1002/pip.2724

69. Nath, M.; Chakraborty, S.; Kim, K. H.; Johnson, E. V.; Roca i Cabarrocas, P.; Chatterjee, P. Phys. Status Solidi C 2010, 7 , 1105-1108. doi:10.1002/pssc.200982726

70. Dundar, I.; Krichevskaya, M.; Katerski, A.; Acik, I. O. R. Soc. Open Sci. 2019, 6, 181578. doi:10.1098/rsos.181578

71. Kim, G. M.; Tatsuma, T. Sci. Rep. 2017, 7, 10699 doi:10.1038/s41598-017-11193-1

72. Blum, M.; Weinhardt, L.; Fuchs, O.; Bär, M.; Zhang, Y.; Weigand, M.; Krause, S.; Pookpanratana, S.; Hofmann, T.; Yang, W.; Denlinger, J. D.; Umbach, E.; Heske, C. Rev. Sci. Instrum. 2009, 80, 123102. doi:10.1063/1.3257926 


\section{License and Terms}

This is an Open Access article under the terms of the Creative Commons Attribution License (http://creativecommons.org/licenses/by/4.0). Please note that the reuse, redistribution and reproduction in particular requires that the authors and source are credited.

The license is subject to the Beilstein Journal of Nanotechnology terms and conditions: (https://www.beilstein-journals.org/bjnano)

The definitive version of this article is the electronic one which can be found at:

doi:10.3762/bjnano. 10.230 